\title{
EPIDEMIOLOGICAL STUDIES OF LEPROSY IN AICHI PREFECTURE
}

\author{
Akihiro SOBUE \\ (The Sanitary Department, Aichi Prefecture)
}

An epidemiological investigation was carried out on new cases of leprosy between 1906 and 1957 in Aichi Prefecture, mainly in the following leprosaria: Nagashima Aisei-en, Kuryu Rakusen-en, and the Suruga Leprosarium. The findings are as follows.

1. During the 50 years from 1906 to $1957,1,546$ new cases were found and the incidence rates were between 0.1 and 1.6 per 10,000 population. The average number of new cases in one year is therefore 29,7 .

2. The prevalence rate was 24.7 per 10,000 population at the highest, and 5.3 at the lowest. The number of leprosy patients have come to decrease recently.

3. New cases were most frequently observed between the ages of 15 and 19 , or $19.7 \%$ in rate, and $63.1 \%$ of the total cases had begun between the ages of 10 and 29 .

4. The disease type $\mathrm{L}$ was observed in $59.6 \%$, the type $\mathrm{M}$ in $17.0 \%$, and the type $\mathrm{N}$ in 23.4\%. The type ratio $(\mathrm{L} / \mathrm{M}+\mathrm{N})$ was 1.47 and has been remarkably improved in the term of Showa (1926-57) in comparison with that in the terms of Meiji (1906-11) and Taisho (1911-1926).

5. The sex ratio was 259.5 during the above mentioned years, and 460.0 in the term of Taisho at the highest, but recently it decreased to 162.2 .

6. $42.6 \%$ of the total cases had one or more other patients in their own families.

7. In $35.5 \%$ of the total cases the symptoms began in Spring; this rate is a little higher than that in other seasons.

8. $75.6 \%$ of the total patients or 1,170 in number, was admitted in leprosaria. In the term of Meiji or Taisho the rate of the patients admitted in leprosaria was lower, but gradually the length of their home residences were shortened. In recent years the patients are admitted in leprosaria immediately after the onset of the disease.

9. In younger patients the period of their home residences were relatively longer, but a comparatively high rate of them were admitted in leprosaria, while the older whose home residences were stabilized, were admitted in leprosaria in lower rate.

10. $7.1 \%$ of the total cases were diagnosed to be recovered generally, $45.7 \%$ were dead, $24.3 \%$ were returned to their own homes. The patients treated in their homes were 1.41 per 10,000 population at the highest, and $0.41 \%$ at the lowest which was recorded recently. 


\title{
愛知県における攋の疫学的研究
}

\author{
祖父江昭仁 \\ 愛 知 県衛生部(部長小川朝吉博士) \\ 名古屋大学医学部予防医学教室 (指尊 岡田 博教授) \\ (昭和 34 年 10 月 12 日受稿)
}

\section{緒言}

らいがらい菌によつて起る伝病染であるとと注今日疑 のないところであるが，初発疹が欠如し潜伏期が判然と しないために，その感染状態を明磪に証明しがたいの で,らいの疫学については, 殆えど明らかにさ机ていな い。

愛知県仗従来上り，全国屈指のらい県といわれ，明治 以来, 数次にわたる調査が行われてきたが, 大正 8 年の 全国的な在宅患者の調査”によ水ば，県下には1,080人 の患者があつたといわれ，鹿䍐島，沖緡につぐ多らい県 として述べられているぶ，近時は患者の著明な減少をみ ている。しかし，昭和 29 年の厚生省の資料2)にると， な蚛既知患者 87 人, 収容患者 427 人となつて小り, 年 \& 30 人前後の新届出患者学みている状態であつて, 必 ずしも楽観を許さざるものがある。

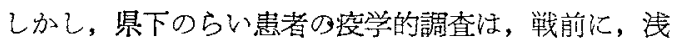
野3)，田中 ${ }^{4)}$, 清水 ${ }^{55}$ 亿よる名古屋大学外来らい患者の動 向についての観察㧍よび光田6)による謂查成績以外に は，㱠えど調査されておらず，特に戦後に㧍ける患者の 動向は全く明らかにされていないので,らいの疫学的特 性を鮮明にし，今後のらい予防の資料とするたるに，要

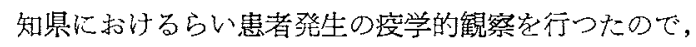
これを報告する。

\section{研究資料および研究方法}

昭和 30 年春以来 2 力年にわたり, 愛知県出身のらい患 者の最も多く入所しているらい療養所, 即方長島愛生園 多磨全生園，栗生楽家園および国立駿河潦養所における 死亡, 退所客含さ全入所忠者, ならびに盼治39年以降昭 和32年末までにおける県下全在宅患者について察荃所に おける検診票，患者台帳並びに県保有の患者台帪と現地 調查とにより調查を行つた。

調查項目注氏名, 性別, 生年月日, 病型, 職業, 国
籍, 出生地, 発病地, 発病年月日, 発病から入所までの 年月，家族内蟔者の保有状況などである。

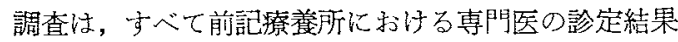
の明らかなもののみについて行つたが，一部栗生楽泉園 関係の分法火災のために詳細な記録が失わ秃ているの でこて氺につては，当該事頁の明らかではいものは不 明として処理した。

また患者の出身地，発病地，現住地等については，古 くから保管されている県の患者台帳と照合したものを使 用した。在宅患者についても国立駿河療養所の専門医師 による診定結果および名古屋大学医学部皮ふ科の医師に よる䛦定結果の明らかなるのを集計した。

即ち，明治末期より昭和 32 年に至る約 50 年䦓における 新発病患者を調査の対象としたが，在宅のまま経過した 患者の中，明治時代ならびに大正初期のものは，その殆 えどが資料不備であり，診断根拋む明確でないので，診 定医師名の明確なむので，確実にらい筷患之把握し得た ものの文とした。

な㧍, 病型については現在新病型区分に变りつつある が778，䛦断当時の病型ををのまま使用するより方法が ないので，これをそのま使用し，L型(結節型)，M 型 (斑紋型)，N型 (神経型)の 3 型に分類した。

人口について滛知県統計課発行の愛知県人口の資 料9゙により，䍜患摔ほ人口10万に対する率を算出し， 小数第 2 位を 4 捨 5 入した。年命階級区分は 5 才階級別 を埰用した。

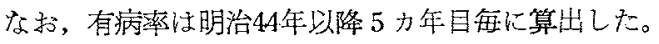

\section{研 究成 績}

1）患者発病状況（第 1表なよび第 1 図）

明治 39 年以来昭和 32 年に至る約 50 年間における患者総 数は 1,546名で, 1 力年当り平均患者数は 29.7 名であ つた。

年次別に, 最も多くの患者の発病をみたのは昭和17年 
第 1 表 発病年次別男女別らい患者発病状㳸

\begin{tabular}{|c|c|c|c|c|c|c|c|c|c|c|c|}
\hline \multirow{2}{*}{ 発病年次硯 } & \multicolumn{2}{|l|}{ 奏 } & 数 & \multicolumn{3}{|c|}{ 人口10万效 } & \multicolumn{3}{|c|}{ 人口10万対 3 力年平均羅患率 } & \multirow{2}{*}{$\begin{array}{l}5 \text { 力集 } \\
\text { 羅患率 }\end{array}$} & \multirow{2}{*}{$\begin{array}{l}\text { 集平均 } \\
\text { 虫者数 }\end{array}$} \\
\hline & 尌 & 等 & 女 & 訫 & 男 & 女 & 計 & 寻 & 女 & & \\
\hline $\begin{array}{r}\text { 明沿 } 39(1906) \\
40(1907) \\
41(1908) \\
42(1909) \\
43(1910)\end{array}$ & $\begin{array}{r}24 \\
11 \\
8 \\
15 \\
36\end{array}$ & $\begin{array}{r}19 \\
5 \\
6 \\
11 \\
26\end{array}$ & $\begin{array}{r}5 \\
6 \\
2 \\
4 \\
10\end{array}$ & $\begin{array}{l}1.3 \\
0.6 \\
0.4 \\
0.8 \\
1.8\end{array}$ & $\begin{array}{l}2.1 \\
0.5 \\
0.6 \\
1.1 \\
2.3\end{array}$ & $\begin{array}{l}0.6 \\
0.7 \\
0.2 \\
0.4 \\
1.0\end{array}$ & $\begin{array}{l}0 . \overline{8} \\
0.6 \\
1.0 \\
0.9\end{array}$ & $\begin{array}{l}1 . \overline{1} \\
0.7 \\
1.3 \\
1.4\end{array}$ & $\begin{array}{l}0 . \overrightarrow{5} \\
0.4 \\
0.5 \\
0.5\end{array}$ & 1.0 & 18.8 \\
\hline $\begin{array}{r}44(1911) \\
\text { 大正. } 1(1912) \\
2(1913) \\
3(1914) \\
4(1915)\end{array}$ & $\begin{array}{r}4 \\
13 \\
16 \\
16 \\
19\end{array}$ & $\begin{array}{r}4 \\
11 \\
9 \\
13 \\
14\end{array}$ & $\begin{array}{l}0 \\
2 \\
7 \\
3 \\
5\end{array}$ & $\begin{array}{l}0.2 \\
0.6 \\
0.8 \\
0.8 \\
0.9\end{array}$ & $\begin{array}{l}0.4 \\
1.1 \\
0.9 \\
1.2 \\
1.3\end{array}$ & $\begin{array}{l}0 \\
0.2 \\
0.7 \\
0.3 \\
0.5\end{array}$ & $\begin{array}{l}0.9 \\
0.5 \\
0.7 \\
0.8 \\
0.9\end{array}$ & $\begin{array}{l}1.3 \\
0.8 \\
1.1 \\
1.1 \\
1.5\end{array}$ & $\begin{array}{l}0.4 \\
0.3 \\
0.4 \\
0.5 \\
0.3\end{array}$ & 0.7 & 13.6 \\
\hline $\begin{array}{l}5(1916) \\
6(1917) \\
7(1918) \\
8(1919) \\
9(1920)\end{array}$ & $\begin{array}{l}23 \\
16 \\
20 \\
29 \\
24\end{array}$ & $\begin{array}{l}21 \\
11 \\
16 \\
22 \\
22\end{array}$ & $\begin{array}{l}2 \\
5 \\
4 \\
7 \\
2\end{array}$ & $\begin{array}{l}1.1 \\
0.7 \\
0.9 \\
1.4 \\
1.1\end{array}$ & $\begin{array}{l}2.0 \\
1.0 \\
1.5 \\
2.1 \\
2.1\end{array}$ & $\begin{array}{l}0.2 \\
0.5 \\
0.4 \\
0.7 \\
0.2\end{array}$ & $\begin{array}{l}0.9 \\
0.9 \\
1.0 \\
1.1 \\
1.3\end{array}$ & $\begin{array}{l}1.4 \\
1.5 \\
1.4 \\
1.9 \\
2.1\end{array}$ & $\begin{array}{l}0.4 \\
0.4 \\
0.5 \\
0.4 \\
0.5\end{array}$ & 1.1 & 22.4 \\
\hline $\begin{array}{l}10(1921) \\
11(1922) \\
12(1923) \\
13(1924) \\
14(1925)\end{array}$ & $\begin{array}{l}30 \\
17 \\
32 \\
27 \\
22\end{array}$ & $\begin{array}{l}24 \\
14 \\
26 \\
21 \\
16\end{array}$ & $\begin{array}{l}6 \\
3 \\
6 \\
6 \\
6\end{array}$ & $\begin{array}{l}1.4 \\
0.8 \\
1.5 \\
1.2 \\
0.9\end{array}$ & $\begin{array}{l}2.2 \\
1.3 \\
2.4 \\
1.9 \\
1.4\end{array}$ & $\begin{array}{l}0.6 \\
0.3 \\
0.5 \\
0.5 \\
0.5\end{array}$ & $\begin{array}{l}1.1 \\
1.2 \\
1.2 \\
1.2 \\
1.2\end{array}$ & $\begin{array}{l}1.9 \\
2.0 \\
1.9 \\
1.9 \\
2.0\end{array}$ & $\begin{array}{l}0.3 \\
0.5 \\
0.4 \\
0.5 \\
0.5\end{array}$ & 1.1 & 25.6 \\
\hline $\begin{array}{r}\text { 昭和 } 1(1926) \\
2(1927) \\
3(1928) \\
4(1929) \\
5(1930)\end{array}$ & $\begin{array}{l}36 \\
29 \\
24 \\
37 \\
23\end{array}$ & $\begin{array}{l}30 \\
24 \\
20 \\
25 \\
16\end{array}$ & $\begin{array}{r}6 \\
5 \\
4 \\
12 \\
7\end{array}$ & $\begin{array}{l}1.5 \\
1.2 \\
0.9 \\
1.5 \\
0.9\end{array}$ & $\begin{array}{l}2.6 \\
2.0 \\
1.6 \\
2.0 \\
1.3\end{array}$ & $\begin{array}{l}0.5 \\
0.4 \\
0.3 \\
0.9 \\
0.5\end{array}$ & $\begin{array}{l}1.2 \\
1.2 \\
1.2 \\
1.1 \\
1.1\end{array}$ & $\begin{array}{l}2.0 \\
2.1 \\
1.9 \\
1.6 \\
1.5\end{array}$ & $\begin{array}{l}0.5 \\
0.4 \\
0.5 \\
0.6 \\
0.6\end{array}$ & 1.2 & 29.8 \\
\hline $\begin{array}{r}6(1931) \\
7(1932) \\
8(1933) \\
9(1934) \\
10(1935)\end{array}$ & $\begin{array}{l}22 \\
43 \\
45 \\
61 \\
51\end{array}$ & $\begin{array}{l}15 \\
36 \\
36 \\
4.1 \\
33\end{array}$ & $\begin{array}{r}7 \\
7 \\
9 \\
20 \\
18\end{array}$ & $\begin{array}{l}0.8 \\
1.6 \\
1.7 \\
2.2 \\
1.8\end{array}$ & $\begin{array}{l}1.2 \\
2.7 \\
2.7 \\
3.0 \\
2.3\end{array}$ & $\begin{array}{l}0.5 \\
0.5 \\
0.7 \\
1.4 \\
1.2\end{array}$ & $\begin{array}{l}1.1 \\
1.4 \\
1.8 \\
1.9 \\
1.8\end{array}$ & $\begin{array}{l}1.7 \\
2.2 \\
2.8 \\
2.7 \\
2.4\end{array}$ & $\begin{array}{l}0.5 \\
0.6 \\
0.9 \\
1.1 \\
1.1\end{array}$ & 1.6 & 44.4 \\
\hline $\begin{array}{l}\text { II }(1936) \\
\text { i2 }(1937) \\
13(1938) \\
14(1939) \\
\text { is }(1940)\end{array}$ & $\begin{array}{l}38 \\
36 \\
71 \\
52 \\
49\end{array}$ & $\begin{array}{l}29 \\
25 \\
55 \\
35 \\
33\end{array}$ & $\begin{array}{r}9 \\
11 \\
16 \\
17 \\
16\end{array}$ & $\begin{array}{l}1.3 \\
1.3 \\
2.3 \\
1.7 \\
1.5\end{array}$ & $\begin{array}{l}2.0 \\
1.7 \\
3.7 \\
2.3 \\
2.1\end{array}$ & $\begin{array}{l}0.6 \\
0.7 \\
1.0 \\
1.1 \\
1.0\end{array}$ & $\begin{array}{l}1.5 \\
1.6 \\
1.7 \\
1.9 \\
1.8\end{array}$ & $\begin{array}{l}2.0 \\
2.5 \\
2.5 \\
2.7 \\
2.4\end{array}$ & $\begin{array}{l}0.8 \\
0.8 \\
0.9 \\
1.0 \\
1.1\end{array}$ & 1.6 & 49.2 \\
\hline $\begin{array}{l}16(1941) \\
17(1942) \\
18(1943) \\
19(1944) \\
20(1945)\end{array}$ & $\begin{array}{l}67 \\
76 \\
36 \\
20 \\
19\end{array}$ & $\begin{array}{l}47 \\
57 \\
26 \\
11 \\
13\end{array}$ & $\begin{array}{r}20 \\
19 \\
10 \\
9 \\
6\end{array}$ & $\begin{array}{l}2.4 \\
2.3 \\
1.0 \\
0.6 \\
0.7\end{array}$ & $\begin{array}{l}2.9 \\
3.4 \\
1.5 \\
0.7 \\
0.9\end{array}$ & $\begin{array}{l}1.2 \\
1.1 \\
0.6 \\
0.5 \\
0.4\end{array}$ & $\begin{array}{l}2.0 \\
1.8 \\
1.3 \\
0.8 \\
0.6\end{array}$ & $\begin{array}{l}2.8 \\
2.3 \\
1.9 \\
1.0 \\
0.8\end{array}$ & $\begin{array}{l}1.1 \\
1.0 \\
0.7 \\
0.5 \\
0.4\end{array}$ & 1.5 & 43.6 \\
\hline $\begin{array}{l}21(1946) \\
22(1947) \\
23(1948) \\
24(1949) \\
25(1950)\end{array}$ & $\begin{array}{l}16 \\
31 \\
33 \\
29 \\
33\end{array}$ & $\begin{array}{l}10 \\
23 \\
19 \\
18 \\
19\end{array}$ & $\begin{array}{r}6 \\
8 \\
14 \\
11 \\
14\end{array}$ & $\begin{array}{l}0.7 \\
0.9 \\
1.0 \\
0.9 \\
0.9\end{array}$ & $\begin{array}{l}0.7 \\
1.5 \\
1.2 \\
1.1 \\
1.2\end{array}$ & $\begin{array}{l}0.4 \\
0.5 \\
0.8 \\
0.6 \\
0.8\end{array}$ & $\begin{array}{l}0.7 \\
0.9 \\
1.0 \\
1.0 \\
0.8\end{array}$ & $\begin{array}{l}1.0 \\
1.1 \\
1.3 \\
1.2 \\
1.0\end{array}$ & $\begin{array}{l}0.4 \\
0.6 \\
0.6 \\
0.7 \\
0.6\end{array}$ & 0.8 & 28.4 \\
\hline $\begin{array}{ll}26 & (1951) \\
27 & (1952) \\
28 & (1953) \\
29 & (1954) \\
30 & (1955)\end{array}$ & $\begin{array}{l}20 \\
17 \\
17 \\
18 \\
25\end{array}$ & $\begin{array}{l}14 \\
13 \\
10 \\
10 \\
13\end{array}$ & $\begin{array}{r}6 \\
4 \\
7 \\
8 \\
12\end{array}$ & $\begin{array}{l}0.6 \\
0.5 \\
0.5 \\
0.5 \\
0.7\end{array}$ & $\begin{array}{l}0.8 \\
0.8 \\
0.6 \\
0.6 \\
0.7\end{array}$ & $\begin{array}{l}0.3 \\
0.2 \\
0.4 \\
0.4 \\
0.6\end{array}$ & $\begin{array}{l}0.7 \\
0.5 \\
0.5 \\
0.5 \\
0.5\end{array}$ & $\begin{array}{l}0.9 \\
0.7 \\
0.7 \\
0.6 \\
0.6\end{array}$ & $\begin{array}{l}0.4 \\
0.3 \\
0.3 \\
0.5 \\
0.4\end{array}$ & 0.5 & 19.4 \\
\hline $\begin{array}{l}31(1956) \\
32(1957)\end{array}$ & $\begin{array}{r}13 \\
8\end{array}$ & $\begin{array}{l}9 \\
5\end{array}$ & $\begin{array}{l}4 \\
3\end{array}$ & $\begin{array}{l}0.3 \\
0.2\end{array}$ & $\begin{array}{l}0.5 \\
0.3\end{array}$ & $\begin{array}{l}0.2 \\
0.2\end{array}$ & 0.4 & 0.5 & 0.3 & \} 0.2 & 10.5 \\
\hline मे & 1.497 & 1,081 & 416 & 1.1 & 1.6 & 0.6 & $\cdot$ & $\cdot$ & $\cdot$ & $\cdot$ & $\cdot$ \\
\hline 年 次不晶 & 49 & 35 & 14 & $\cdot$ & $\cdot$ & $\cdot$ & $\cdot$ & $\cdot$ & $\cdot$ & $\cdot$ & $\cdot$ \\
\hline 伡 & 1.546 & 1,116 & 430 & $\cdot$ & $\cdot$ & - & $\cdot$ & $\cdot$ & $\cdot$ & - & 29.7 \\
\hline
\end{tabular}

で 76 名定示し年次不明患者 49 名起除く全患者の $5.1 \%$ で，次いて昭和13年 71 名，4.7\%，昭和16年 67 名， $4.5 \%$ といずれも昭和中期の戦争前後の頃に著明で，最 む患者発病の少なかつたの明明治41年ならびに昭和 32 年 のそれぞれ 8 名，0.5\%であつた。これ人口 10 万対率 飞て只ると，や沙り昭和中期飞著明で，昭和16年は人口 10 万対 2.4 を示し，次いで浩炤和 $13 ， 17$ 年の 2.3 , 昭和 9 年 2.2 となり, 最む低いのは明治44年ならびに昭和 32

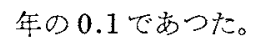

時代別に患者発病の経過をみると，明治末期（明治39 〜3年） 5 力年間には，年平均患数 18.8 名で，人口 10 万対 1.0 であるが, 大正中期（大正 5 9 年）より増加 の傾向をみせ，年平均患者数す20名を越すと共に䍜患率 も 1.1 上上具を夕せた。更にこの傾向は昭和に入ると急 激俚增加定夕女，昭和 6 年以降法 5 力年平均䍜患率も

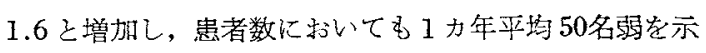


第 1 図 年次別 3 力年平均羅患率 (人口10万対)

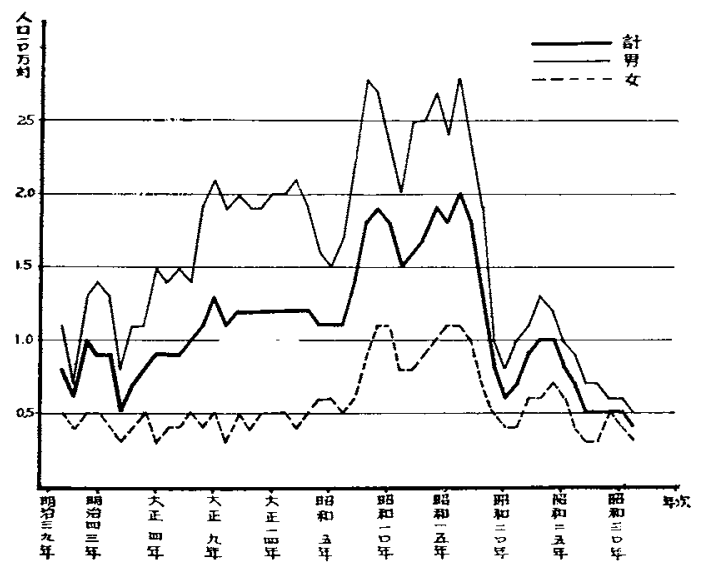

したが，この傾向は昭和中期（昭和 $11 〜 20$ 年）も同様で 戦争中（昭和 16 20 年）は年平均患者数 43.6 名, 人口 10 万対 1.5 で経過し戦後の過程に入つている。戦後の 5 力年間では平均患者数 28.4 名と戦争ならびに 戦後の湿 乱時代にもかかわらず患者の発病は減少の傾向を多せ， 人口10万対率に执いても0.8と減少をみせている。最近

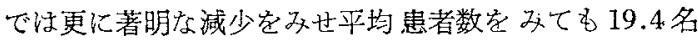
と 20 名を割り，人口 10 万対率においても 0.5 を示して 索り, 最近の 2 力年間では 10.5 名, 0.2 と, 昭和初期中

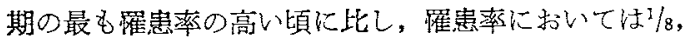
平均患者数においても $1 / 4$ 〜 $1 / 5$ の減少を示すに至つてい \%。

このととは，3力年平均罹患率についてみると，更に 明瞅で, 明治末期以来, 若干の変動はあるが，次第に罹

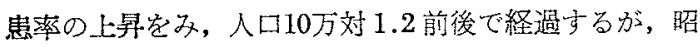
和 7 年以降急激な増加をみせ, 昭和 10 年には 1.9 とピー ク觉形成し，以後 $2 \sim 3$ 年間には若干の減少をみせたが 昭和12年以降再び增加をみ昭和16年には 2.0 と最も 高、罹患率を示した。しかし，元の後は，戦時中にもか かわらず，急激に減少に転じ，昭和20年には0.6 定し た。戦後，昭和 21 年以降は，敗戦による国民生活の混乱 のためか，再び0.9〜1.0 と增加の傾向定みせているが，

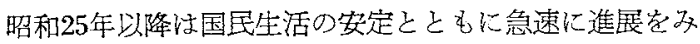
せた諸般の公咅衛生事業の飛躍的な進展ならびに行政庁 による患者の隔離措置の強化ととむに最近では，0.5 上 り 0.4 を示すに至つている。

更に 3 力年平坛䍜患率の变遷を男女別に多ると, 男女 間に著しい相異が認められる。即ち，男性では，既に大 正 5 年頃より急激な堌加傾向を多せてをり，大正 8 年以 降は，抒おむね 2.0 前後で経過したが，昭和 5 年には 1.5 と减少をみせたものの，その後は $2.0 〜 2.80$ 高率の
まま昭和21年以降の過程に入つている。

女性で注, 明治末期以来昭和 5 年頃玉では, 男性の増 加にもかがらず，ほぼ 0.5 前後で経過し，昭和 8 年以 降やや增加して 1.1 を示したが，昭和19年に法 0.5 之減 少し, 戦後の過程に移行している。

戦後は，男女之も，ほぼ同じ傾向で経過し昭和 31 年に 注男 0.5 , 女 0.3 宗した。

\section{2) 有病率 (第 2 表)}

第 2 表 主要年次患者数 (有病率) (人口10万対)

\begin{tabular}{|c|c|c|c|c|c|c|c|c|}
\hline 年 & 区 & 分 & 患 & 者 & 数 & 有 & 病 & 率 \\
\hline 明治 & 43 & $(1910)$ & & 94 & & & 5.25 & \\
\hline 大正 & 4 & (1915) & & 159 & & & 8.18 & \\
\hline 大正 & 9 & (1920) & & 261 & & & 12.49 & \\
\hline 昭 私 & 1 & (1925) & & 375 & & & 36.17 & \\
\hline 昭 和 & 5 & $(1930)$ & & 498 & & & 19.43 & \\
\hline 昭和 & 10 & (1935) & & 656 & & & 22.92 & \\
\hline 昭和 & 15 & (1940) & & 781 & & & 24.67 & \\
\hline 昭科 & 20 & (1945) & & 771 & & & 24.69 & \\
\hline 昭 和 & 25 & (1950) & & 714 & & & 21.06 & \\
\hline 昭和 & 30 & (1955) & & 678 & & & 17.71 & \\
\hline 昭和 & 32 & (1957) & & 672 & & & 17.56 & \\
\hline
\end{tabular}

明治39年以降 5 力年目每に患者数它みて子当と，明治 43 年には94名の患者を有し，人口 10 万対 5.25 であつた が，その後は時代の経過と乙もに增加の傾向宗し，昭 和 15 年には 781 名の最も多くの患者数印にたが，人口 10 万対においても24.67 と增加をみせた。戦中はそのま ま経過したが，この傾问以昭和 25 年にいたり 714.名， 21.06 と新患者発生の減少むむつて，やや減少の傾向を みせたが，近年にいたり更に減少し，昭和30年には 678 名, 17.71となつた。

\section{3）患者数の変遷ならびに転㷌（第 3 表）}

明治39年以降昭和 32 年末まで打ける患者総数 1,546 名中, 発病時期不明の患者 49 名を除く 1,497 名の患者 の発病時期別患者数の变遷ならびに転帰について子ると 明治 43 年末に括汀る総患者数 94 名の中，4名注入所し， 90名洼在宅患者であつたが，大正 4 年末には，更に68名 の新患者定加光，患者総数は 162 名となつたが，入所患 者もまた12名定みた。しかし，入所後死亡した患者 3 名 之退所し再び在宅患者となつた患者1名をみているの で, 入所患者総数は 8 名, 在宅患者は 151 名で, 入所患 者の添ぼ 19 倍の在宅患者を放ている。大正 9 年末儿注 29 名の入所患㨋の中, 死亡 11 名之退所患者 2 名を外た ため，入所中のものは16名で，在宅虫者 245 名老数光， 
第 3 表 患 者 数 の 变 遷

\begin{tabular}{|c|c|c|c|c|c|c|c|c|c|c|c|c|c|c|c|c|}
\hline \multirow{2}{*}{ 年区 分 } & \multirow{2}{*}{\multicolumn{2}{|c|}{ 急者発病数 }} & \multirow{2}{*}{ 患者超数 } & \multicolumn{2}{|c|}{ 入 } & \multicolumn{3}{|c|}{ 所 } & \multicolumn{3}{|c|}{ 在 } & \multicolumn{3}{|c|}{ 宅 } & \multirow{2}{*}{$\begin{array}{l}\text { 在 宅 } \\
\text { 患者 数 }\end{array}$} & \multirow{2}{*}{$\begin{array}{ll}\text { 入 } & \text { 所 } \\
\text { 患者效 }\end{array}$} \\
\hline & & & & 大 所 & 死 & $\dot{L}$ & & 所 & 入 所 & 死 & $亡$ & 取 & 消 & 退所住宅 & & \\
\hline \multirow{2}{*}{$\begin{array}{c}\text { 明治 } 39 \\
\text { l } \\
\text { 明治 } 43\end{array}$} & 計 & 94 & 94 & 4 & & - & & - & - & & - & & - & - & 90 & 4 \\
\hline & $\begin{array}{l}\text { 男 } \\
\text { 女 }\end{array}$ & $\begin{array}{l}67 \\
27\end{array}$ & $\begin{array}{l}67 \\
27\end{array}$ & 4 & & $\overline{-}$ & & $\overline{-}$ & - & & $\overline{-}$ & & $\overline{-}$ & $\overline{-}$ & $\begin{array}{l}63 \\
27\end{array}$ & $\frac{4}{-}$ \\
\hline \multirow{2}{*}{$\begin{array}{l}\text { 明治 } 44 \\
\text { 大正 } 4\end{array}$} & 計 & 68 & 162 & 4 & & 3 & & 1 & 8 & & - & & - & 1 & 151 & 8 \\
\hline & $\begin{array}{l}\text { 罗 } \\
\text { 女 }\end{array}$ & $\begin{array}{l}51 \\
17 \\
\end{array}$ & $\begin{array}{r}118 \\
44\end{array}$ & 4 & & $\begin{array}{l}2 \\
1\end{array}$ & & 1 & $\begin{array}{l}6 \\
2 \\
\end{array}$ & & $\overline{-}$ & & $\overline{-}$ & 1 & $\begin{array}{r}109 \\
42\end{array}$ & $\begin{array}{l}7 \\
1 \\
\end{array}$ \\
\hline \multirow{2}{*}{$\begin{array}{l}\text { 大正 } 5 \\
\text { ? } \\
\text { 犬正 } 9\end{array}$} & 計 & 112 & 274 & 9 & & 11 & & 2 & 20 & & 1 & & 1 & 2 & 245 & 16 \\
\hline & $\begin{array}{l}\text { 界 } \\
\text { 女 }\end{array}$ & $\begin{array}{l}92 \\
20\end{array}$ & $\begin{array}{r}210 \\
64\end{array}$ & 9 & & $\begin{array}{l}9 \\
2\end{array}$ & & $\frac{2}{-}$ & $\begin{array}{r}16 \\
4\end{array}$ & & 1 & & 1 & $\stackrel{2}{-}$ & $\begin{array}{r}185 \\
60\end{array}$ & $\begin{array}{r}14 \\
2\end{array}$ \\
\hline \multirow{2}{*}{$\begin{array}{l}\text { 大正 } 10 \\
\text { 大让 } 14\end{array}$} & 計 & 128 & 402 & 14 & & 21 & & 6 & 52 & & 5 & & 1 & 6 & 336 & 39 \\
\hline & $\begin{array}{l}\text { 男 } \\
\text { 女 }\end{array}$ & $\begin{array}{r}101 \\
27\end{array}$ & $\begin{array}{r}311 \\
91 \\
\end{array}$ & 14 & & $\begin{array}{r}17 \\
4 \\
\end{array}$ & & $\begin{array}{l}5 \\
1 \\
\end{array}$ & $\begin{array}{r}43 \\
9 \\
\end{array}$ & & 5 & & 1 & $\begin{array}{l}5 \\
1 \\
\end{array}$ & $\begin{array}{r}253 \\
83 \\
\end{array}$ & $\begin{array}{r}35 \\
4 \\
\end{array}$ \\
\hline \multirow{2}{*}{ 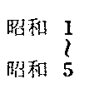 } & 計 & 149 & 551 & 28 & & 41 & & 13 & 127 & & 10 & & 1 & 12 & 397 & 101 \\
\hline & $\begin{array}{l}\text { 思 } \\
\text { 䒺 }\end{array}$ & $\begin{array}{r}115 \\
34\end{array}$ & $\begin{array}{l}426 \\
125\end{array}$ & $\begin{array}{r}25 \\
3\end{array}$ & & $\begin{array}{r}35 \\
6\end{array}$ & & $\begin{array}{r}11 \\
2\end{array}$ & $\begin{array}{r}104 \\
23\end{array}$ & & $\begin{array}{l}9 \\
1\end{array}$ & & $\frac{1}{-}$ & 11 & $\begin{array}{r}298 \\
99\end{array}$ & $\begin{array}{l}83 \\
18\end{array}$ \\
\hline \multirow{2}{*}{ 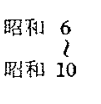 } & 計 & 222 & 773 & 76 & & 99 & & 23 & 270 & & 16 & & $I$ & 22 & 432 & 224 \\
\hline & $\begin{array}{l}\text { 男 } \\
\text { 女 }\end{array}$ & $\begin{array}{r}161 \\
61\end{array}$ & $\begin{array}{l}587 \\
186\end{array}$ & $\begin{array}{l}56 \\
20\end{array}$ & & $\begin{array}{l}86 \\
13\end{array}$ & & $\begin{array}{r}20 \\
3\end{array}$ & $\begin{array}{r}223 \\
47\end{array}$ & & $\begin{array}{r}14 \\
2\end{array}$ & & 1 & $\begin{array}{r}20 \\
2\end{array}$ & $\begin{array}{l}313 \\
119\end{array}$ & $\begin{array}{r}172 \\
52\end{array}$ \\
\hline \multirow{2}{*}{$\begin{array}{l}\text { 昭和 } 11 \\
\text { l } \\
\text { 昭和 } 15\end{array}$} & iे & 246 & 1.019 & 140 & & 186 & & 57 & 420 & & 42 & & 6 & 53 & 464 & 317 \\
\hline & $\begin{array}{l}\text { 塄 } \\
\text { 女 }\end{array}$ & $\begin{array}{r}177 \\
69 \\
\end{array}$ & $\begin{array}{l}764 \\
255\end{array}$ & $\begin{array}{r}107 \\
33\end{array}$ & & $\begin{array}{r}148 \\
38 \\
\end{array}$ & & $\begin{array}{l}47 \\
10 \\
\end{array}$ & $\begin{array}{r}324 \\
96 \\
\end{array}$ & & $\begin{array}{r}34 \\
8\end{array}$ & & 6 & $\begin{array}{r}47 \\
6 \\
\end{array}$ & $\begin{array}{l}340 \\
124 \\
\end{array}$ & $\begin{array}{r}233 \\
84 \\
\end{array}$ \\
\hline \multirow{2}{*}{ 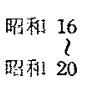 } & 計 & 218 & 1,237 & 189 & & 369 & & 93 & 581 & & 78 & & 8 & 82 & 463 & 308 \\
\hline & $\begin{array}{l}\text { 男 } \\
\text { 安 }\end{array}$ & $\begin{array}{r}154 \\
64\end{array}$ & $\begin{array}{l}918 \\
319\end{array}$ & $\begin{array}{r}142 \\
47\end{array}$ & & $\begin{array}{r}293 \\
76\end{array}$ & & $\begin{array}{l}68 \\
25\end{array}$ & $\begin{array}{l}443 \\
138\end{array}$ & & $\begin{array}{l}60 \\
18\end{array}$ & & $\begin{array}{l}7 \\
1\end{array}$ & $\begin{array}{l}68 \\
14\end{array}$ & $\begin{array}{l}334 \\
129\end{array}$ & $\begin{array}{r}215 \\
93\end{array}$ \\
\hline \multirow{2}{*}{$\begin{array}{l}\text { 嘿利 } 21 \\
\text { ? } \\
\text { 昭和 } 25\end{array}$} & 榙 & 142 & 1.379 & 259 & & 477 & & 117 & 727 & & 136 & & 39 & 104 & 322 & 392 \\
\hline & 男 & $\begin{array}{l}89 \\
53\end{array}$ & $\begin{array}{r}1,007 \\
372\end{array}$ & $\begin{array}{r}189 \\
70\end{array}$ & & $\begin{array}{l}362 \\
115\end{array}$ & & $\begin{array}{l}85 \\
32\end{array}$ & $\begin{array}{l}542 \\
185\end{array}$ & & $\begin{array}{r}107 \\
29\end{array}$ & & $\begin{array}{r}31 \\
8\end{array}$ & $\begin{array}{l}85 \\
19\end{array}$ & $\begin{array}{r}223 \\
99\end{array}$ & $\begin{array}{l}269 \\
123\end{array}$ \\
\hline \multirow{2}{*}{$\begin{array}{l}\text { 昭和 } 26 \\
\text { ? } \\
\text { 昭和 } 30\end{array}$} & 誥 & 97 & 1,476 & 325 & & 514 & & 137 & 818 & & 169 & & 98 & 120 & 186 & 492 \\
\hline & $\begin{array}{l}\text { 男 } \\
\text { 女 }\end{array}$ & $\begin{array}{l}60 \\
37\end{array}$ & $\begin{array}{r}1,067 \\
409\end{array}$ & $\begin{array}{r}226 \\
99\end{array}$ & & $\begin{array}{l}381 \\
133\end{array}$ & & $\begin{array}{l}98 \\
39 \\
\end{array}$ & $\begin{array}{l}596 \\
222\end{array}$ & & $\begin{array}{r}131 \\
38\end{array}$ & & $\begin{array}{l}71 \\
27\end{array}$ & $\begin{array}{l}97 \\
23\end{array}$ & $\begin{array}{r}140 \\
46\end{array}$ & $\begin{array}{l}328 \\
164\end{array}$ \\
\hline \multirow{2}{*}{ 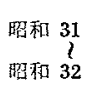 } & 計 & 21 & 1,497 & 343 & & 518 & & 138 & 829 & & 181 & & 109 & 121 & 156 & 516 \\
\hline & $\begin{array}{l}\text { 罗 } \\
\text { 㚣 }\end{array}$ & $\begin{array}{r}14 \\
7\end{array}$ & $\begin{array}{r}1,081 \\
416\end{array}$ & $\begin{array}{l}238 \\
105\end{array}$ & & $\begin{array}{l}383 \\
135\end{array}$ & & $\begin{array}{l}99 \\
39\end{array}$ & $\begin{array}{l}604 \\
225\end{array}$ & & $\begin{array}{r}139 \\
42\end{array}$ & & $\begin{array}{l}79 \\
30\end{array}$ & $\begin{array}{l}98 \\
23\end{array}$ & $\begin{array}{r}119 \\
37\end{array}$ & $\begin{array}{l}345 \\
171\end{array}$ \\
\hline
\end{tabular}

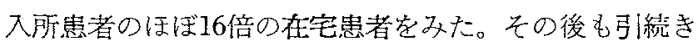
新患者の堌加とともに, 入所患者, 在宅患者も急激に增 加し，昭和10年末では入所中患者 224 名, 在宅患者 432 名となつているが，昭和時化に入つて著明なのは在宅患 者の入所するものの增加が著明になつたことで昭和10年 末むでにおける在宅患者で入所したものは 270 名を数党 ている。しかし反面入所患者の死亡を99名，在宅患者 の死亡 16 名学数え，退所患者も23名を数えているが， その中，22名は再び在宅虫者となつている。

昭和 15 年末 末，更に新患者 246 名多数え，患者総数 1,019名となつたが，入所患者も560名となり，死亡患 者 186 名, 退所患者 57 名安数元るので，入所中の患者 江 317 名，在宅患者は退所在宅者53名を扣えて 464. 名 となつている。
昭和20年末における入所中患者は 308 名, 在宅患者は 463 名である。

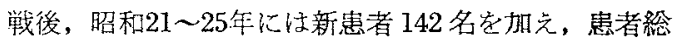
数 1,379名定数元るが，入所率の向上とともに 216 名の 多数の患者の入所を文，入所中の死亡等を除き，入兹忠 者数は 392 名, 在宅患者数は 322 名と, はじめて入所忠 者と在宅患者の比方逆転をみせている。昭和30年末にお ける在宅患者は 186 名, 入所患者 492 名である。

昭和32年末におけるほぼ50年間の総虫者の状沇は，入 所中死亡総数 518 名, 在宅のまま死亡したもの181 名で 入所せるも何らふの理由により退所した患者は138名で そのゆ121名は退所传在宅しているすのであつた。なた 特に戦後は症状固定により軽快治ゆ者として，らい患者 台帳より抹消せられたものの増加をみとめ，32年末には 
総数 109 名にのぼつている。徒つて昭和 32 年末における 入所患者は 516 名 (男 345 名, 女 171 名) で, 在宅患者 煺所在者含奶 156 名（男 119 名, 女 37 名) に及 えでいる。

\section{4) 発病年令}

a）全患者発病年令（第 4 表执よび第 2 図）

第 4 表 男女別 5 于階級年令別発病年令

\begin{tabular}{|c|c|c|c|c|}
\hline \multirow{2}{*}{ 年令区分 } & 棇 & 男 & 女 & \multirow{2}{*}{ 埄些 } \\
\hline & 実 数 $(\%)$ & 哭 数 $(\%)$ & 実 数 (\%) & \\
\hline $0 \sim 4$ & $1(0.06)$ & $1(0.09)$ & - & - \\
\hline $5 \sim 9$ & $73(5.0)$ & $44(4.1)$ & $29(7.1)$ & 151.7 \\
\hline $10 \sim 14$ & $195(13.4)$ & $14.1(13.4)$ & $54(13.3)$ & 261.1 \\
\hline $15 \sim 19$ & 257 (17.1) & $193(18.4)$ & $64(15.8)$ & 301.6 \\
\hline $20 \sim 24$ & $234(16.0)$ & $176(16.7)$ & $58(14.2)$ & 303.4 \\
\hline $25 \sim 29$ & $179(12.3)$ & $149(14.1)$ & $30(7,4)$ & 496.7 \\
\hline $30 \sim 34$ & $115(7.9)$ & $88(8.3)$ & $27(6.7)$ & 325.9 \\
\hline $35 \sim 39$ & $97(6.7)$ & $68(6.4)$ & $29(7.1)$ & 234.5 \\
\hline $40 \sim 44$ & $66(4.5)$ & $43(4.0)$ & $23(5.7)$ & 187.0 \\
\hline $45 \sim 49$ & $70(4.8)$ & $37(3.5)$ & $33(8.1)$ & 112.1 \\
\hline $50 \sim 54$ & $57(3.9)$ & $36(3.4)$ & $21(5.2)$ & 171.4 \\
\hline $55 \sim 59$ & $42(2.9)$ & $30(2.8)$ & $12(3.0)$ & 250.0 \\
\hline $60 \sim 64$ & $35(2,4)$ & $22(2.0)$ & $13(3.2)$ & 169.2 \\
\hline $65 \sim 69$ & $15(1.0)$ & $12(1.1)$ & $3(0.7)$ & 400.0 \\
\hline $70 \sim 74$ & $11(0.8)$ & $7(0.6)$ & $4(1.0)$ & 175.0 \\
\hline $75 \sim 79$ & $6(0.4)$ & $2(0.1)$ & $4(1.0)$ & 50.0 \\
\hline $80 \sim$ & $4(0.3)$ & $2(0.1)$ & $2(0.5)$ & 100.0 \\
\hline 小 棓 & $1,457(100.0)$ & $1.051(100.0)$ & $406(100.0)$ & 258.9 \\
\hline 年舍不詳 & 89 & 65 & 24 & 270.8 \\
\hline 計 & 1.546 & 1.116 & 430 & 259.5 \\
\hline$<39 / 40<$ & 3.7 & 4.5 & 2.5 & - \\
\hline$<19 / 60<$ & 7.4 & 8.4 & 5.6 & - \\
\hline 平均年令 & 27.9 & 27.2 & 29.6 & - \\
\hline
\end{tabular}

第 2 図 発病年令分布曲線

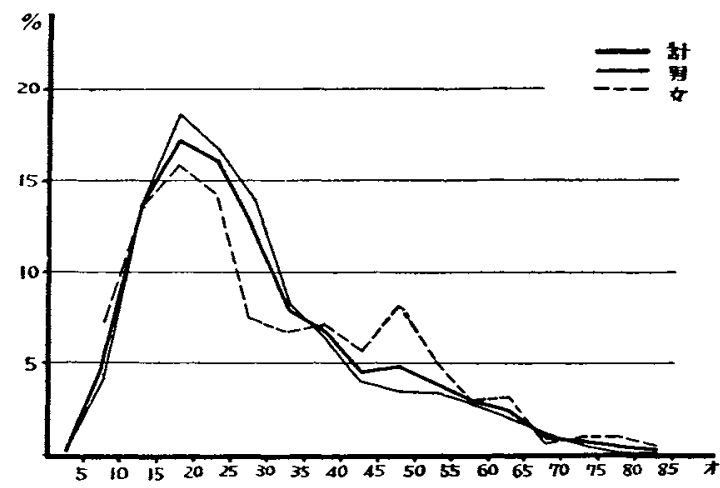

忠者綕数1,546名中, 発病年令推定可能な患者は 1,457 名で，との発病年令分布を 5才階級別にみると15１9才 に最も高く $17.1 \%$ を示し，次いで 20〜24才の $16.0 \%$ ，
10〜14才の $13.4 \% ， 25 \sim 29$ 才の $12.3 \%$ で，10〜29才の 年令層に和ける発病は全体の $58.8 \%$ 占めている。

60 才以上の高令者の発病は総数 71 名で $4.9 \%$ に み れた。

らいの老化を知るに重要といかれている，39才と40才 前後比10) (<39/40<と記載す) および，19才前と60才 以後の比 ${ }^{10)}(<19 / 60<$ と記載す）について多ると，前 者は 3.7 , 後者は 7.4 で, 全患者の平均発病年令は 27.9 寸である。

\section{b）男女別発病年令}

男女別に発病年令皆多と，男女子も15１9才に最も 高率を示し，全患者の発病年合分布とほぼ同様の結果を 示している。即ち男では15〜19才の発病は 18.4\%で, 続いて 20〜24 于の 16.7\%，10〜14才 13.4\%，25２9才 14.1\%となり，10２9才の年令層における発病性62.6\% を占め，60才以上の発病は 3.9\%である。

女性では 15〜19 于の発病は 15.8\%，次いで 20〜24才 $14.2 \% ， 10 \sim 14$ 才 $13.3 \%$ で，10〜29 才の発病は $50.7 \%$ で，男性に比しかなりの低率を示している。60才以上の 発病は $6.4 \%$ で, 男に比し高令者発病の割合が高い。こ のことは，女では男に比し，比較的 30 才以上の中年層 における発病が著明であること意味し，平均発病年命 をみても男の 27.2 年に対し，女では29.6年と 2.4 年の 差がみられ，更に<39/40<では男 4.5, 女 $2.5 ，<19$ ) $60<$ では男 8.4，女5.6といずれをみても，この傾向が らかがわれる。

男女別に発病年令分布曲線を双ると，9才以前では男 の比率に比し女の分布がやや多く，思春期以降は男のて れに比し，女の年令分布はやや低率であるが，36子以降 は再び女の比率の增加努名ている。

発病年令別に性比をみてみると，5～9才の151.7よ り，年令の長ずるに従つて性比は増大し，25〜29才には 496.7 と最大に達し，思春期以降，中年層むでにおける 男性癷病の著明なこと宗してをり，30才以降は再び年 令の增加とともに，お抾放減少する倾沟を示している 方，50才以降は65６9才の 400.0 除き，169.2〜250.0 の間定している。

c）発病時期別発病年令（第 5 表および第 3 図）

発病時期別に平均発病年命についてみると, 明治時代 に注平均 22.1 年で, 以下時代の経過とともに大正初期 では平均 24.6 年と潮次增大寸る傾向を多せたが，大正 末期には 21.2 年と再び平均年令の若年化がうかがわれ た。しかし，その後は年々增加の傾向を示し，昭和11〜 15 年には 28.3 年と増加し, その後も戦争ならびに戦後 
第 5 表 発病時期别発病年令（人口 10 万対）

\begin{tabular}{|c|c|c|c|c|c|c|c|c|c|c|c|c|c|c|}
\hline 発病斯 & & & 大正 $5 \sim 9$ & 大正10 14 & 昭和 $1 \sim 5$ & 昭和 $6 \sim 10$ & 照和I I I5 & 昭和 $16 \sim 20$ & 炤科21 25 & 昭租 $26 \sim 30$ & 昭和 $31 \sim 32$ & & & \\
\hline 発病䇬令、 & $\begin{array}{r}(1906 \sim \\
1910)\end{array}$ & $\begin{array}{c}(1911 \sim \\
1915)\end{array}$ & $\begin{array}{r}(1916 \sim \\
1920) \\
\end{array}$ & $\begin{array}{c}(1921 \sim \\
1925)\end{array}$ & $\begin{array}{r}(1926 \sim \\
1930)\end{array}$ & $\begin{array}{r}(1931 \sim \\
1935)\end{array}$ & $\begin{array}{r}(1936 \sim \\
1940) \\
\end{array}$ & $\begin{array}{c}(1941 \\
1945)\end{array}$ & $\begin{array}{r}(1946 \sim 20 \\
1950)\end{array}$ & $\begin{array}{c}(1951 \sim \\
1955)\end{array}$ & $\begin{array}{c}(1956 \sim \\
1957)\end{array}$ & 小訫 & 衃 & 訂 \\
\hline $0 \sim 4$ & - & - & - & - & $1(0.06)$ & - & - & - & - & - & - & & & \\
\hline $5 \sim 9$ & $11(1.0)$ & $5(0,4)$ & $13(1.0)$ & $5(0.4)$ & $7(0.5)$ & $6(0.4)$ & $8(0.5)$ & $9(0.5)$ & $4(0.4)$ & $5(0.2)$ & - & 73 & & 73 \\
\hline $10 \sim 14$ & $13(1.4)$ & $9(0.9)$ & $11(0.9)$ & $35(2.54)$ & $26(1.9)$ & $30(1.9)$ & $27(1.5)$ & $20(1.2)$ & $17(1.0)$ & $5(0.2)$ & $1(0.05)$ & 194 & & 195 \\
\hline $15 \sim 19$ & $16(2.0)$ & $12(1.3)$ & $23(2,2)$ & $25(2.08)$ & $35(2,39)$ & $52(3.41)$ & $43(2.4)$ & $30(2.6)$ & $14(0.8)$ & $5(0.2)$ & $I(0.04)$ & 256 & & 257 \\
\hline $20 \sim 24$ & $12(1.5)$ & $11(1.4)$ & $19(2.2)$ & $25(2.48)$ & $28(2.43)$ & $45(3.35)$ & $44(3.1)$ & $23(1.7)$ & $21(1.3)$ & $4(0,2)$ & $2(0.1)$ & 234 & & 234 \\
\hline $25 \sim 29$ & $15(2.0)$ & $12(1.6)$ & $16(2.2)$ & $14(1.7)$ & $17(1.7)$ & $29(2.6)$ & $32(2.4)$ & $22(2.1)$ & $13(1.1)$ & $8(0.5)$ & $1(0.06)$ & 179 & & 179 \\
\hline $30 \sim 34$ & $5(0,7)$ & $6(0.8)$ & $13(1.9)$ & $7(1.0)$ & $6(0.7)$ & $14(1,4)$ & $I 8(1.6)$ & $18(1.7)$ & $15(1.4)$ & $13(1.1)$ & - & 115 & & 115 \\
\hline $35 \sim 39$ & $3(0.6)$ & $4(0.6)$ & $6(0.9)$ & $6(0.9)$ & $8(1.1)$ & $13(1.6)$ & $18(1.9)$ & $21(2.1)$ & $8(0.8)$ & $10(0.9)$ & -1 & 97 & & 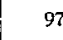 \\
\hline $40 \sim 44$ & $3(0.6)$ & $2(0.4)$ & $6(1.0)$ & $4(0.6)$ & $2(0.3)$ & $8(1.2)$ & $13(1.7)$ & $9(1.1)$ & $8(0.9)$ & $9(0.8)$ & $2(0.2)$ & 66 & & \\
\hline $45 \sim 49$ & $2(0.5)$ & $4(0.9)$ & $I(0.2)$ & $2(0.3)$ & $7(1.1)$ & $8(1.3)$ & $10(1.5)$ & $16(2.1)$ & $10(1.2)$ & $8(0.9)$ & $2(0.2)$ & 70 & & 70 \\
\hline $50 \sim 54$ & $1(0,2)$ & $I(0.3)$ & $2(0.5)$ & $3(0.7)$ & $4(0.7)$ & $7(1.2)$ & $9(1.5)$ & $11(2.2)$ & $11(1.7)$ & $6(0.7)$ & $2(0.2)$ & 57 & & \\
\hline $55 \sim 59$ & $2(0.5)$ & - & $1(0.3)$ & - & - & $4(0.9)$ & $5(0.9)$ & $11(2.1)$ & $7(1.1)$ & $9(1.4)$ & $3(0.5)$ & 42 & & \\
\hline $60 \sim 64$ & - & - & $1(0.3)$ & - & $3(1.0)$ & $2(0.6)$ & $8(1.8)$ & $7(1.5)$ & $9(1.95)$ & $3(0.6)$ & $2(0,4)$ & 35 & & 35 \\
\hline $65 \sim 69$ & - & - & - & -1 & - & - & $3(1.3)$ & $2(0.5)$ & $1(0.3)$ & $5(1.3)$ & $4(1.4)$ & 15 & & 1 \\
\hline $70 \sim 74$ & - & $I(0.6)$ & - & - & $I(0.5)$ & - & $1(0.5)$ & $4(1.6)$ & $3(1.2)$ & $1(0,3)$ & - & 11 & & 11 \\
\hline $75 \sim 79$ & - & - & - & - & - & - & $1(0.9)$ & $4(3.3)$ & - & $I(0.2)$ & - & 6 & & \\
\hline 80 以上 & - & - & - & - & - & - & 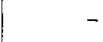 & - & - & $3(0.3)$ & $1(0.1)$ & & & \\
\hline 小 計 & 83 & 67 & 112 & 126 & 145 & 218 & 240 & 207 & 141 & 95 & 21 & 1,455 & 2 & 1.457 \\
\hline 年合不詳 & II & 1 & - & 2 & 4 & 4 & 6 & 11 & 1 & 2 & - & 42 & 247 & 89 \\
\hline 部 & 94 & 68 & 112 & 128 & 149 & 222 & 246 & 218 & 142 & 97 & 21 & 1.497 & 49 & 1.546 \\
\hline$<39 / 40<$ & 9.4 & 7 & 9.2 & 13.0 & 7.5 & 6.5 & 3.8 & 2.2 & 1.9 & 1.1 & 0.3 & & : & \\
\hline$<19 / 60<$ & ss & 26.0 & 47.0 & s & 17.3 & 44.0 & 6.0 & 3.5 & 2.7 & 1.2 & 0.3 & & & \\
\hline 平均年令 & 22.06 & 24.61 & 23.43 & 21.21 & 23.45 & 24.84 & 28.33 & 32.65 & 33.17 & 39.63 & 48.90 & & 15 & \\
\hline
\end{tabular}

第 3 図 発病時期別発病年令

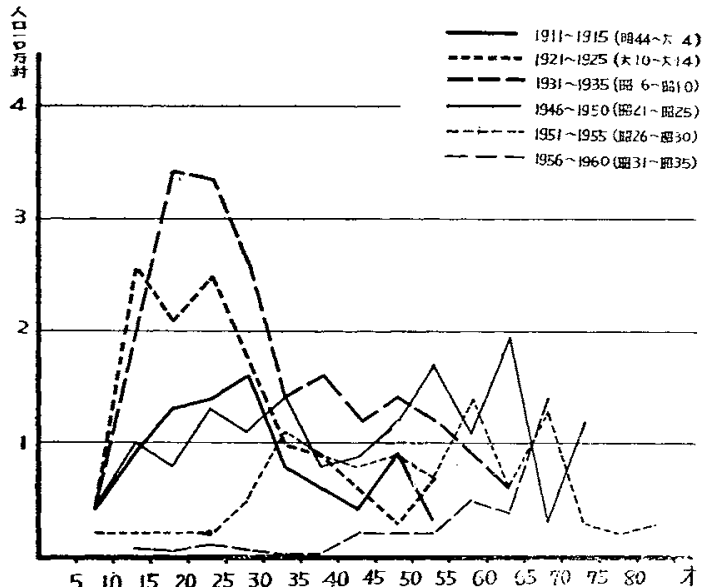

の湿乱時代にもかかわらず著㛣な影暃を文せず 32.7 年と 老化学示し，戦後は更に著朋な老化傾问定示している。

$<39 / 40<,<19 / 60<$ ，について子ても，前者では明 治時代の 9.4より, 大正時代に入ると 7.4 13.0 と若年

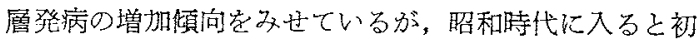
期には7.5を示したが，その後は次第に減少し，昭和11 年以降には 3.8 と新発满患者の增加にもかかからず老化
㑯向を示し，戦中，戦後もひきつづき減少し，最近では 1.1 之若年, 老年㞗発病に差が殆んどみられない。後者 についてみても全く同様で，昭和11年以降は6.0〜3.5と

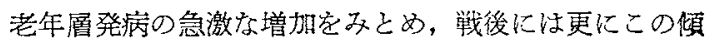
向が著明で，最近では 0.3 と䟕老年層の発病が上廹 る様相を示している。

因みに発湠时期別に5子階級別に患者の百分比它みて みると，明治末期には10２9才における発病は67.6\%で 60才以上の発病者は認めず，お和稀この僋向は炤和10 年に至るまで続くが，その後は10２9才の年令層の占め る割合は次第に減少定示し，昭和26３0年には $23.2 \%$ を 示すにすきない。即台, 明治, 大正特代には，5い患者 の発病年令はその $/ 3$ 年/5が30才前の若年周であつたが， 昭和時代に入ると，その比率加次第に減少するととむに 60才以上の老年層の発病がみられるに至り，年の後洨次 第に増加して，昭和26３0年には13.9\%と老年層の占め る割全が著しく増加している。

即方，昭和11年以降は発病年命の面では著明な老化現 象を示し，戦中戦後の混乱期にもこの老化現象はそのな ま漸進し，戦後には更にきわだつた老化宗している。

発病年次剈に発病年令分布学比較してみると, 明治, 大正时代にはそれぞれ10〜29才に峰をもつた典型的な発 
第 6 表 発病時期別男女別発病年令（人口10万対）

\begin{tabular}{|c|c|c|c|c|c|c|c|c|c|c|c|c|c|c|c|c|c|c|c|c|c|c|c|c|}
\hline \multirow{3}{*}{ 年令区分 } & \multicolumn{4}{|c|}{$\begin{array}{l}\text { 明治 } 39 \sim 43 \\
(1906 \sim 1910)\end{array}$} & \multicolumn{4}{|c|}{$\begin{array}{c}\text { 明治 } 44 \sim \text { 大正 } 4 \\
(1911 \sim 1915)\end{array}$} & \multicolumn{4}{|c|}{$\begin{array}{l}\text { 大正 } 5 \sim 97 \\
(1916 \sim 1920)\end{array}$} & \multicolumn{4}{|c|}{$\begin{array}{l}\text { 大正 } 10 \sim 14 \\
(1921 \sim 1925)\end{array}$} & \multicolumn{4}{|c|}{$\begin{array}{l}(1926 \sim 1930) \\
(1902 \text { 和 }\end{array}$} & \multicolumn{4}{|c|}{$\begin{array}{l}\text { 昭和 } 6 \sim 10 \\
(1931 \sim 1935)\end{array}$} \\
\hline & \multicolumn{2}{|c|}{ 男 } & \multicolumn{2}{|c|}{ 女 } & \multicolumn{2}{|c|}{ 男 } & \multicolumn{2}{|c|}{ tx } & \multicolumn{2}{|c|}{ 男 } & \multicolumn{2}{|c|}{ 女 } & \multicolumn{2}{|c|}{ 男 } & \multicolumn{2}{|c|}{ 女 } & \multicolumn{2}{|c|}{ 男 } & \multicolumn{2}{|l|}{ 女 } & \multicolumn{2}{|r|}{ 男 } & \multicolumn{2}{|r|}{ 女 } \\
\hline & 実数 1 & 10 万対 & 実数 1 & 10 万対 & 実数 1 & 0万対 & 実数 10 & 0 万対 & 実数 10 & 10 万社 & 実数 I & 10 万站 & 実数 1 & 10 万剂 & 数 10 & 10万刘 & 夷数 1 & 10 万対， & 実数 10 & o万対| & 実数 1 & 10万対寻 & 果数 & 10 万対 \\
\hline $0 \sim 4$ & - & & $-\vdots$ & & - & & - & & 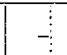 & & 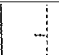 & & $-\vdots$ & & - & & 1 & 0.11 & 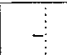 & & $\begin{array}{c}\vdots \\
-\vdots \\
-\vdots\end{array}$ & & - & \\
\hline $5 \sim 9$ & 5 & 0.94 & 6 & 1.16 & 3 & 0.53 & 2 & 0.36 & $9:$ & 1.37 & 4 & 0.62 & 5 & 0.77 & - & & 5 & 0.68 & 2 & 0.28 & 2 & 0.24 & 4 & 0.49 \\
\hline $10 \sim 14$ & $8:$ & 1.73 & 5 & 1.12 & 6 & 1.15 & 3 & 0.59 & 10 & 1.74 & 1 & 0.17 & 27 & 4.06 & 8 & 1.13 & 19 & 2.89 & 7 & 1.02 & 21 & 2.77 & 9 & 1.11 \\
\hline $15 \sim 19$ & I4: & 3.39 & 2 & 0.51 & 10 & 2.19 & 2 & 0.46 & 19 & 3.83 & 4 & 0.74 & 22 & 3.71 & 3 & 0.46 & 29 & 4.17 & 6 & 0.78 & 39 & 5.43 & 13 & 1.61 \\
\hline $20 \sim 24$ & $10:$ & 2.50 & 2 & 0.52 & 9 & 2.26 & 2 & 0.53 & 17 & 4.01 & 2 & 0.47 & 20 & 3.98 & 5 & 0.99 & 20 & 3.50 & 8 & 1.38 & 32 & 4.99 & 13 & 1.85 \\
\hline $25 \sim 29$ & $11 !$ & 2.90 & 4 & 1.06 & 8 & 2.08 & 4 & 1.07 & 16 & 4.30 & $-\vdots$ & & 13 & 3.00 & 1 & 0.24 & 16 & 3.15 & $1:$ & 0.21 & 22 & $3.83 !$ & 7 & 1.28 \\
\hline $30 \sim 34$ & 4 & 1.18 & $\mathbf{1}$ & 0.30 & 6 & 1.66 & - & & 11 & 3.24 & 2 & 0.60 & 5 & 1.34 & 2 & 0.57 & 3 & 0.69 & 3 & 0.75 & 10 & 2.00 & 4 & 0.86 \\
\hline $35 \sim 39$ & 1 & 0.39 & 2 & 0.81 & 3 & 0.91 & 1 & 0.31 & 5 & 1.50 & $1 \vdots$ & 0.30 & 3 & 0.87 & 3 & 0.92 & 6 & 1.62 & 2 & 0.59 & 12 & 2.81 & 1 & 0.26 \\
\hline $40 \sim 44$ & 3 & 1.24 & $-\vdots$ & & 2 & 0.81 & 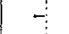 & & 3 & 0.99 & 3 & 1.00 & 3 & 0.91 & 1 & 0.31 & $1 \vdots$ & 0.30 & 1 & 0.32 & 5 & $1.40^{\prime}$ & 3 & 0.91 \\
\hline $45 \sim 49$ & $1 !$ & 0.49 & 1 & 0.51 & 3 & 1.30 & $\mathbf{1}$ & 0.46 & $\because$ & & 1 & 0.44 & - & & 2 & 0.69 & 5 & 1.58 & 2 & 0.64 & 5 & 1.55 & 3 & 0.99 \\
\hline $50 \sim 54$ & $1:$ & 0.47 & - & & - & & 1 & 0.48 & 1 & 0.51 & 1 & 0.52 & 3 & 1.37 & - & & 3 & 1.09 & $1 \vdots$ & 0.36 & 4 & 1.36 & 3 & 1.01 \\
\hline $55 \sim 59$ & $1 !$ & 0.54 & $\mathbf{1}$ & 1.22 & - & & - & & 1 & 0.63 & 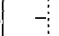 & & -- & & - & & $\begin{array}{l}\vdots \\
-\vdots\end{array}$ & & 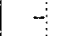 & & 4 & 1.61 & - & \\
\hline $60 \sim 64$ & $-\vdots$ & & - & & $-i$ & & $-\vdots$ & & - & & 1 & 0.61 & $-\vdots$ & & - & & 3 & 2.01 & 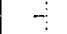 & & 2 & 1.18 & $-\vdots$ & \\
\hline $65 \sim 69$ & 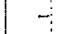 & & - & & $-\vdots$ & & 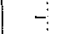 & & - & & 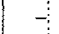 & & - & & - & & 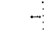 & & - & & - & & 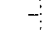 & \\
\hline $70 \sim 74$ & $-\vdots$ & & - & & 1 & 1.31 & 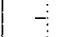 & & 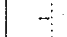 & & 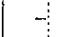 & & - & & $\vdots$ & & 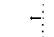 & & 1 & 0.93 & $-\vdots$ & & - & \\
\hline $75 \sim 79$ & $-\vdots$ & & 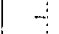 & & $-\vdots$ & & $-\vdots$ & & 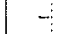 & & 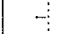 & & - & & $\therefore$ & & - & & $-\vdots$ & & 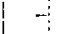 & & -1 & \\
\hline $80 \sim$ & $\because$ & & $-:$ & & $-\vdots$ & & $-a$ & & - & & 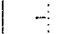 & & - & & $\begin{array}{c}\vdots \\
-\vdots\end{array}$ & & $\vdots$ & & $\vdots$ & & - & & - & \\
\hline 不 詳 & 8 & & 3 & & $-\vdots$ & & $\mathbf{1}$ & & - & & \begin{tabular}{c}
$\vdots$ \\
\hdashline$\vdots$
\end{tabular} & & 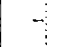 & & 2 & & 4 & & $\begin{array}{c}\vdots \\
-\vdots \\
-\vdots\end{array}$ & & 3 & & $I_{1}$ & \\
\hline
\end{tabular}

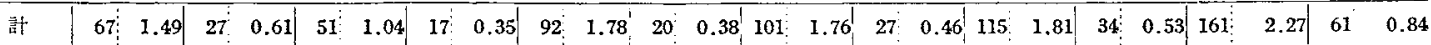

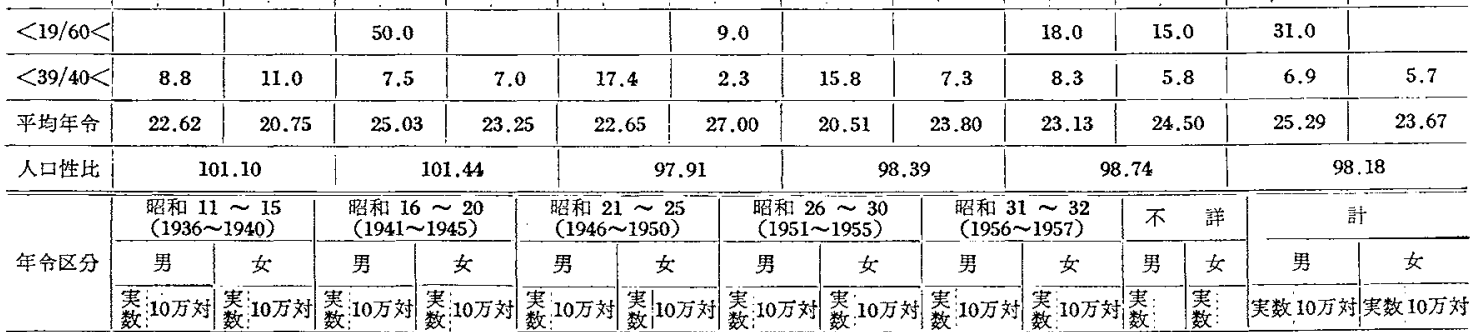

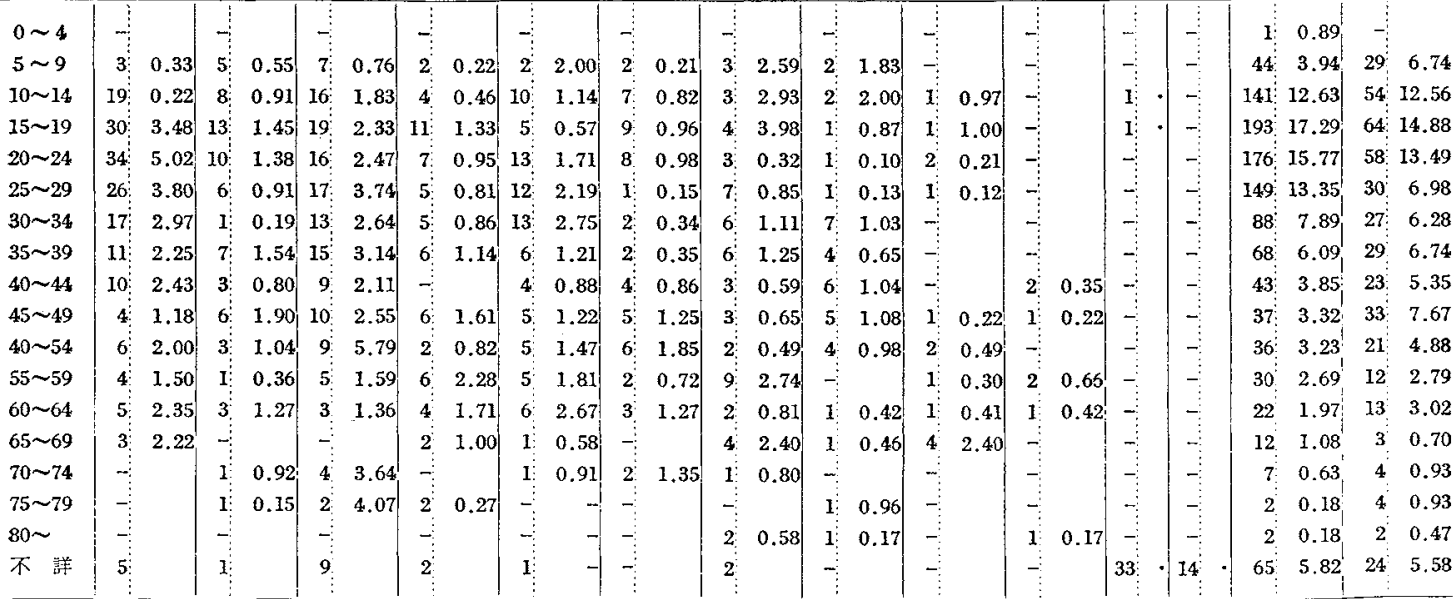

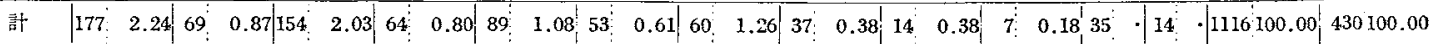

\begin{tabular}{r|r|r|r|r|r|r|r|r|r|r|r|r|r|r|r}
\hline$<19 / 60<$ & 6.5 & 5.2 & 4.7 & 2.1 & 2.1 & 3.6 & 1.1 & 1.3 & 0.4 & 0 & $\cdot$ & 8.4 & 5.7 \\
\hline$<39 / 40<$ & 4.4 & 2.8 & 2.5 & 1.8 & 2.3 & 1.4 & 1.2 & 0.9 & 0.6 & 0 & $\cdot$ & $\cdot$ & 4.5 & 2.5 \\
\hline 平均年令 & 28.02 & 29.13 & 31.55 & 33.61 & 33.25 & 33.04 & 39.76 & 39.43 & 45.57 & 55.57 & $\cdot$ & $\cdot$ & 27.24 & 29.61 \\
\hline 人口性此 & 99.89 & \multicolumn{2}{|c|}{94.88} & \multicolumn{2}{|c|}{94.70} & \multicolumn{2}{|c|}{94.86} & 94.86 & & \\
\hline
\end{tabular}


病年令分布曲線を示すのに対し，昭和時代に入ると，比 較的高令者の発病が著明となるにつれて, 青少年峰が低 下し，壮年老年層の增加が認められ，昭和21年以降は, 特に青少年峰の玫善が著明で, 最近では, 若年尿に殆え どタるべきピークが蛍められず，右方に上乐したなだら かな傾斜線老示すにいたつている。

更に 5 才階級年令別に年次推移学み学上，減少の最も 著明なのは 15〜19寺で，人口10万対につき，明治時代 $2.0 よ り$ 時代の経過とともに堌加をみせ，戦中には 3.5 と最大值定示したが, 戦後は急激な淢少傾问に転じ, 最 近では 0.04 と明治時代の $1 / 50$ に, 戦時最高時のほぼ、 $1 / 90$ と非常な減少をみせている。

次いで 20〜24于，25〜29于，10〜14才に同様な減少 傾向がみられる。

60才以上の老年層に発病定みたのは大正 $5 〜 9$ 年に1 名定ている他は，す心゙て昭和時代に入つてからで，昭 和 1〜5年には4名の発病がみられるが，大の後は特に 昭和11年以降著明となり，人口10万対率で办ると65～69 才では最近に打いても 1.4 と減少家示さず，他の年令の 减少も若年層ほど著明ではない。

明治時代の発病年令順位は15～19才，25～29才，20～ 24才，10〜14才，5〜9才の䐓で，戦前はおお效この 傾向で経過するか戦後には若年層の减少とともに老年層 の進出方著明で，最近では65〜69才，55〜 59才，90〜64 才，40〜44才，45〜49才，50〜54才といずれ高令層が 上位它占, 最下位は15１9才の人口10万対 0.04 とな つている。

\section{d）発病時期別男女别発病年令（第6 表）}

発病時期別に男女別以発病年令をみる，人口10万対 では，明治時代に忹男の平均発病年合は22.6才で，女 の20.8才に比しやや男の発病年令高く，䍜患率の最も 高いのは男では15〜19才 3.39, 女では5 5 -59才 1.22と なつている。

大正初期には平均発病年命情女とも若下の老化をみ せているが，大正 5〜9年で注男の平均発病年令は 22.7 才と若年化を示しているのに，女では27.0于と更に老 化文示している。大正末期には男女とも若年化を示し，

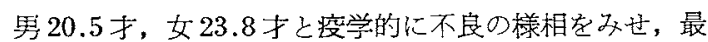
高瞿患率も男 10～14才 4.06，女10～14才 1.13 となつて いる。

昭和初期には男女とも平均発病年令は再び男 23.1 才, 女24.5才と老化定しているが，男女とも，年命分有の 傾向は明治大正時代と著しい相異を示していない。

その後も全く同様で時代の経過とともに，発病年令の
老化を示しているが，60才以上の高令者発病を，男女と むにみるのは明治大正時代と著しくおすをきを異にする とこるである。

戦後, 昭和 $21 \sim 25$ 年の 5 年間は, 平均発病年令では, 戦中の 5 力年間と男女とも殆えど変つていないが，各年 令とも䍜患率の減少ぶ著明である。最近の昭和26３0年 では，男の平均発病年命39.8才，女のそれは39.4才と男 女とも著しく老化文子せてい。

即方，明治・大正時代では平均発病年合家みると，男 女とも動摇を爻せつつ経過し，しかも60才以上の高命者 の発病学殆んどみていないが，昭和時代に入ると，とく に勧中戦後には，平均登病年令の老化が著明となるとと もに高年者の発病を相当数にみるに至つており，このこ とは各年令比をみてす同様にいいうることであるが，男 女別には年令による特異性は見出し得ない。

e ）病型别発病年令（第 7 表）

第 7 丧 5 才階級発痛年令別病型胡患者数

\begin{tabular}{|c|c|c|c|c|c|c|}
\hline 年令区分 & $\begin{array}{c}\mathrm{L} \\
\text { 奏数 }(\mathscr{O})\end{array}$ & $\begin{array}{c}\mathrm{M} \\
\text { 笑数 }(\%)\end{array}$ & $\begin{array}{c}\mathrm{N} \\
\text { 奏数 }(\not)\end{array}$ & $\begin{array}{c}\text { 計 } \\
\text { 実数 }(\%)\end{array}$ & 不詳 & $\begin{array}{l}\left(\frac{1}{\text { 病型比 }}\right. \\
\left(\frac{L}{M+N}\right)\end{array}$ \\
\hline $0 \sim 4$ & - & $I(0.4)$ & & $1(0.07)$ & 0 & - \\
\hline $5 \sim 9$ & $39(4.6)$ & $14(6.0)$ & $20(6.3)$ & $73(5.2)$ & 0 & 1.1 \\
\hline $10 \sim 14$ & $139(16.3)$ & $17(7.3)$ & $35(10.9)$ & I91 (13.6) & 4 & 2.6 \\
\hline $15 \sim 19$ & j184. (21.7) & $17(7.3)$ & $53(16.4)$ & 254 (18.0) & 3 & 2.6 \\
\hline $20 \sim 24$ & $158(18.5)$ & $35(14.9)$ & $34(10.6)$ & $227(16.1)$ & 7 & 2.2 \\
\hline $25 \sim 29$ & $\mathrm{~J} 12$ (13.1) & $29(12.4)$ & $31(9.7)$ & $172(12.2)$ & 7 & 1.8 \\
\hline $30 \sim 34$ & $57(6.7)$ & 27 (11.5) & $25(7.8)$ & $109(7.8)$ & 6 & 1.1 \\
\hline $35 \sim 39$ & $49(5.7)$ & $22(9.4)$ & $23(7.2)$ & $94(6.7)$ & 3 & 1.1 \\
\hline $40 \sim 44$ & $26(3.0)$ & $12(5.1)$ & $23(7.2)$ & $61(4,3)$ & 5. & 0.7 \\
\hline $45 \sim 49$ & $27(3.2)$ & $14(6.0)$ & $23(7.2)$ & $64(4.6)$ & 6 & 0.7 \\
\hline $50 \sim 54$ & $25(2.9)$ & $9(3.8)$ & $17(5.3)$ & $51(3.6)$ & 6 & 0.9 \\
\hline $55 \sim 59$ & $13(1.5)$ & $13(5.6)$ & $13(4.1)$ & $39(2.8)$ & 3 & 0.5 \\
\hline $60 \sim 64$ & $10(1.2)$ & $13(5.6)$ & $12(3.8)$ & $35(2.5)$ & 0 & 0.4 \\
\hline $65 \sim 69$ & $3(0.4)$ & $7(3.0)$ & $5(1.6)$ & 15 ( I. 1$)$ & 0 & 0.2 \\
\hline $70 \sim 74$ & $5(0.6)$ & $I(0.4)$ & $4(1.3)$ & $10(0.7)$ & 1 & 1.0 \\
\hline $75 \sim 79$ & $3(0.4)$ & $2(0.9)$ & $1(0.3)$ & $6(0.4)$ & 0 & 1.0 \\
\hline $80 \sim$ & $2(0.2)$ & $1(0.4)$ & $I(0.3)$ & $4(0.3)$ & 0 & 1.0 \\
\hline 計 & 8520 & $34(100$. & IO & $\$ 06(100.0)$ & $5 \mathrm{I}$ & 1.5 \\
\hline 年令不許 & 23 & 16 & 22 & 61 & 28 & 0.6 \\
\hline 計 & 875 & 250 & 342 & 1,467 & 79 & 1.4 \\
\hline$<39 / 40<$ & 5.3 & 2.2 & 2.2 & 3.2 & & - \\
\hline$<19 / 60<$ & 7.8 & 2.0 & 4.6 & 7.4 & & - \\
\hline 平均年令 & 24.8 & 33.2 & 30.9 & 27.6 & . & - \\
\hline
\end{tabular}

病型の確誌されている患者 1,467 名について，病型別 に発病年令をみると，L型では15〜19才にピークが羿め られ $21.7 \%$ ，次いで 20〜24才，10〜14才の䐜位とな り，10〜29才における年令層発病は71.3\%占めている が，M型では20〜24才にピークがみら礼，14.9\%で10〜 29才の年令層の占める割合は4L.9\%で，残りの大半注高 
命者が占めている。N型でむ，や恃り15〜19才にピーク が叕られ16.4\%で，次いで10〜14于となつており，10〜 29 才の発病は47.6\%であつた。

$<39 / 40<，<19 / 60<$ についてると，L型では前者 5.3 , 後者 7.8 と著しく若年者発病の多き走しており, $\mathrm{M}$ 型では前者 2.2 , 後者 2.0 と若年患者とともに，また 高年者にも多くの発病のあることを物語つている。 $\mathrm{N}$ 型 では前者 2.2 , 後者 4.6 己 $\mathrm{M}$ 型活どではないが, 老年層 発病も相当あることがうががあれる。

平均発病年令で注L型に最も少さく，M型が33.2年と 最も大きい。 $\mathrm{N}$ 型では30.9年と L・M 河型のは添中間值 走している。

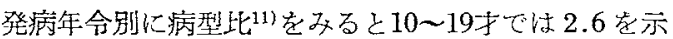
し, 最も病型比大で, 次いで 20〜24才の 2.2，25〜29才 の 1.8 となり，若年層にL型の占める割合の多いことが

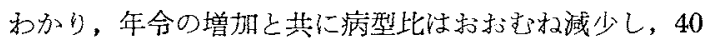
手以上では，逆に $\mathrm{M}+\mathrm{N}>\mathrm{L}$ の様相を示している。即ち 年令の堌加とともにM型， $\mathrm{N}$ 型の増加，L型の減少とな つてあらわ机る。

f）発病年令より夕た在宅患者と収容患者（第 8 表, 第 4 図)

在宅のま経過した患者と潦荃所入収容した患者别に

第 8 表 発病年令別在宅入前別患者数

\begin{tabular}{|c|c|c|c|c|c|c|c|c|}
\hline 区分 & $\overline{\bar{z}}$ & & & 在 & 宅 & $\pi$ & & 所 \\
\hline 㫮級 & 実 数 & 萳分地 & 実 & 数 & 百分比 & 实 数 & 百分比 & 入所率 \\
\hline $0 \sim 4$ & 1 & 0.07 & & 0 & & 1 & 0.1 & 100.0 \\
\hline $5 \sim 9$ & 73 & 5.0 & & 7 & 2.1 & 66 & 5.9 & 90.4 \\
\hline $10 \sim 14$ & 195 & 13.4 & & 13 & 3.8 & 182 & 16.3 & 93.3 \\
\hline $15 \sim 19$ & 257 & 17.6 & & 17 & 5.0 & 240 & 21.4 & 93.4 \\
\hline $20 \sim 24$ & 234 & 16.1 & & 41 & 12.1 & 193 & 17.2 & 82.5 \\
\hline $25 \sim 29$ & 179 & 12.3 & & 46 & 13.6 & 133 & 11.9 & 74.3 \\
\hline $30 \sim 34$ & 115 & 7.9 & & 39 & 11.5 & 76 & 6.8 & 64.3 \\
\hline $35 \sim 39$ & 97 & 6.7 & & 36 & 10.7 & 61 & 5.5 & 62.9 \\
\hline $40 \sim 44$ & $E 6$ & 4.5 & & 29 & 8.6 & 37 & 3.3 & 56.0 \\
\hline $45 \sim 49$ & 70 & 4.8 & & $3 I$ & 9.2 & 39 & 3.5 & 55.7 \\
\hline $50 \sim 54$ & 57 & 3.9 & & 22 & 6.5 & 35 & 3.1 & 61.4 \\
\hline $55 \sim 59$ & 42 & 2.9 & & 20 & 5.9 & 22 & 2.0 & 52.4 \\
\hline $60 \sim 64$ & 35 & 2.4 & & 18 & 5.3 & 17 & 1.5 & 48.5 \\
\hline $65 \sim 69$ & 15 & 1.0 & & 7 & 2.1 & 8 & 0.7 & 53.3 \\
\hline $70 \sim 74$ & 11 & 0.8 & & 6 & 1.8 & 5 & 0.4 & 45.5 \\
\hline $75 \sim 79$ & 6 & 0.4 & & 3 & 0.9 & 3 & 0.3 & 50.0 \\
\hline $80 \sim$ & 4 & 0.3 & & 3 & 0.9 & 1 & 0.1 & 25.0 \\
\hline 小 部 & 1.457 & 100.0 & & 338 & 100.0 & 1,119 & 100.0 & - \\
\hline 不 素 & 89 & - & & 38 & - & 51 & - & - \\
\hline 함 & 1,546 & - & & 376 & - & 1.170 & - & - \\
\hline$<39 / 40<$ & 3.8 & - & & 1.4 & - & 5.6 & - & - \\
\hline$<19 / 60<$ & 7.6 & - & & 3.3 & - & 11.1 & - & - \\
\hline 平均年令 & 26.7 & - & & 34.5 & - & 26.0 & - & - \\
\hline
\end{tabular}

第 4怄 発病年令別入所在宅別表

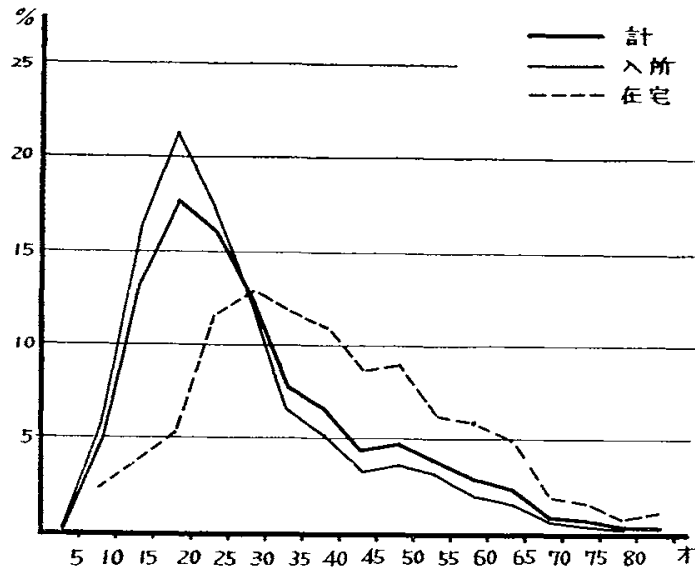

発病年令学みると，平均発病年令では在宅患者の平均 34.5 年に対し，収容患者では26年と両者の間にほぼ10年 の差代热如机る。

<39/40<，<19/60<をみても在它患者では，それだ れ1.4，3.3と収容患者の $6.5 ， 11.1$ に比し，発病年令が 高年令膚の力八偏していることがらかがわれる。

即ち，収容患者では15～19才に21.4\%と最高の割合で 発病者をみるのに対し，在宅患者では，ての最高年令分 布は25〜29才の13.6\%であり，10〜29才の発病は収容患 者では67.4\%に及えでいるのに対し，在宅忠者ではわず か36.0\%にすぎず，30才台発病患者汃 $22.2 \%$ にんでい る。

このことは発病時の年令が大きければ大きいはど，在 宅患者として，居住地に残る傾向が大であることが考え られ，このことは発病年令別患者収容率学欢てむ40才以 上ではそのほぼ半数が在宅莡者として経過している。

5) 病型（第 9 表和よび第 5 図）

総患者 1,546 名中，病型不詳の79名索除く, 病型は, $\mathrm{L}$ 型 875 名で $59.6 \%$ を占め， M型 250 名の，17.0\%，N 型 342 名23.4\%である。病型比 ${ }^{11}$ 注1.47である。

a ) 性别病型

L型で注男 $61.9 \%$ に対し，女では $53.7 \%$ と男に比し， やや低率を示しているが，N型では男 $23.6 \%$ ，女 $22.5 \%$ と両者の間に有意の差学認めないが，M型では男の14.5 \%に比し，女では $23.8 \%$ 女女の比率は男に比し，かなり 高率でL型と逆の分布定示している。

病型比男1.62k娰し，女1.16と女の方に著明な老化 傾何をみる。

b）発病時期之病型

明治時代に発病した患者の病型はL型 $48.9 \% ， \mathrm{M}$ 型 
第9表 発病時期別病型別患者数

\begin{tabular}{|c|c|c|c|c|c|c|c|}
\hline 年 $\underbrace{\text { 分 }}_{\text {次 }}$ & 計 & 計 & L & M & $\mathbf{N}$ & 不 詩 & $\mathrm{L} / \mathrm{M}+\mathbf{N}$ \\
\hline 明治 $39 \sim 43$ & 94 & $94(100.0)$ & $46(48.9)$ & $10(10.6)$ & $38(40.5)$ & 0 & 0.96 \\
\hline 明 $44 \sim 大 ~ 4$ & 68 & $65(100.0)$ & $35(53.9)$ & $7(10.8)$ & $23(35.3)$ & 3 & 1.17 \\
\hline 大正 $5 \sim 9$ & 112 & $109(100.0)$ & $70(64.3)$ & $16(14.6)$ & $23(21.1)$ & 3 & 1.79 \\
\hline 大正 $10 \sim 14$ & 128 & $126(100.0)$ & $92(73.0)$ & $11(0.8)$ & $23(18.2)$ & 2 & 2.71 \\
\hline 昭和 $1 \sim 5$ & 149 & $149(100.0)$ & $101(67.7)$ & $17(11.4)$ & $31(20.9)$ & 0 & 2.10 \\
\hline 䭪租 $6 \sim 10$ & 222 & $217(100,0)$ & $156(71.8)$ & $24(11.1)$ & $37(17.1)$ & 5 & 2.56 \\
\hline 昭和 $11 \sim 15$ & 246 & $236(100.0)$ & $123(52.1)$ & $57(24.1)$ & $56(23.8)$ & 10 & 1.09 \\
\hline 昭和 $16 \sim 20$ & 218 & $208(100.0)$ & $118(56.7)$ & $35(16.8)$ & $55(26.5)$ & 10 & 1.31 \\
\hline 昭和 $21 \sim 25$ & 142 & $133(100.0)$ & $69(51.8)$ & $30(22.5)$ & $34(25.7)$ & 9 & 1.08 \\
\hline 昭利 $26 \sim 30$ & 97 & $87(100.0)$ & $40(45.9)$ & $30(34.4)$ & $17(19.7)$ & 10 & 0.85 \\
\hline 昭和 31 32 & 21 & $21(100.0)$ & $11(52.3)$ & $8(38.1)$ & $2(9.6)$ & 0 & 1.10 \\
\hline 詁 & 1,497 & $1,445(100.0)$ & $861(59.5)$ & $245(16.8)$ & $339(23.7)$ & 52 & 1.4 .7 \\
\hline 年 不 詳 & 49 & $22(100.0)$ & $14(63.6)$ & $5(22.7)$ & $3(13.7)$ & 27 & 1.75 \\
\hline 計 & 1,546 & $1,467(100.0)$ & $875(59.6)$ & $250(17.0)$ & $342(23.4)$ & 79 & 1.47 \\
\hline 男 & 1,116 & $1,063(100.0)$ & $658(61.9)$ & $154(14.5)$ & $251(23.6)$ & 53 & 1.62 \\
\hline 女 & 430 & $404(100.0)$ & $217(53.0)$ & $96(23.8)$ & $91(22.5)$ & 26 & 1.16 \\
\hline 等 & & 59.53 & 322.58 & 160.42 & 275.82 & 203.85 & \\
\hline
\end{tabular}

第 5 図 発病時期别病型の变遷

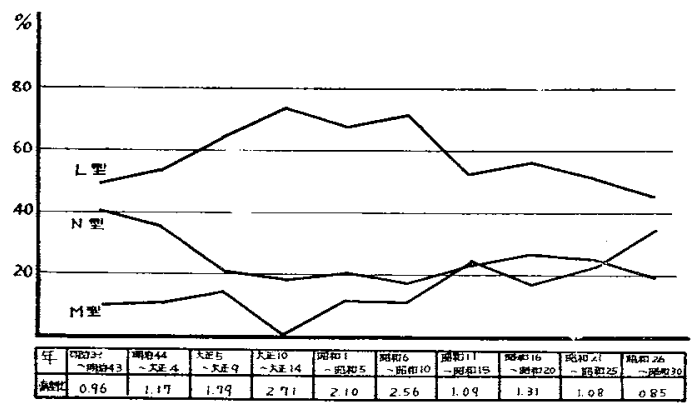

$10.6 \%, \mathrm{~N}$ 型 $40.5 \%$ で，他の年次に比し，N型の占める 割合が著明である。

L型の経過它発病時期別にみると，明治末期より大正 時代にかけて渐增し，大正本期に注 $73.0 \%$ 型発病它 みたが，この傾向は昭和時代に入つても引続きみられる が，昭和11年以降は患者数の增加にもか方和らず漸次 L 型分有は減少の傾向を示しており，最近では45.9\%とな つている。

$\mathrm{N}$ 型も L 型と同じく，明治時代には40.5\%と著明であ

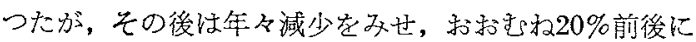
て経過している。

$\mathrm{M}$ 型は明治時代の10.6\%より若下の增減安子つつ経 過し，昭和11～15年に注 $24.1 \%$ 之次第に增加の㥞相定子 せて経過し，最近では $38.1 \%$ となつてい。

従つて病型比は，明治時代より L型の增加とともに増 加し, 大正 $10 \sim 14$ 年には 2.71 と最大定示し, 以後昭和 10
年に至るまでこの傾向定持続しているが，その後はし型 患者の減少，M型患者の増加とあいまつて，減少の偵向 を示し，最近で注0.85を示している。即方，患者の淢少 とともに，L型の減少，M型・N型の増加傾向をみせて いる。

6）性別（第10表および第6図）

1,546名の全患者の性別は，男1,116名，女 430 名で， それで礼72.1\%，27.9\%を占め，その比は，女 100 に対 し，男 259.5 である。

\section{a) 発病時期別性別}

発病時期別化男女の割合をみてみると，明治末期には 男 $71.3 \%$ ，女 $28.7 \%$ を示したが，その後注時代の経過と そもに男の割合の著明な增加索みたが，昭和時代には再 ぞ70\%台となり，年々若干の減少を示しつつ経過したが 戦後恃男の占める割合法 $60 \%$ 台となり，最近で注男61.9 $\%$ ，女 $38.1 \%$ となつている。

従つて性此の時期別変遷で, 明治末期の 248.1 より 次第に増加し，大正 $5 \sim 9$ 年には 460.0 と最も大きかつ たが，その後は次第に男女間の盖が少なくなつて，特に 戦後は 167.9〜162.2 と性比の綰少安みている。この性 比の淢少は, 女性発病者の增加や, 男性発病者のみの著 明な減少のみによるものでないことは，前述せる罹患率 についても明白であり，性比の隇少傾向注著明であると いえよう。

b ) 病型別性別

病型別に性別をみると，L型では，総L型患者の75.2 
第10表 発病時期別男女別忠者数ならびに性比

\begin{tabular}{|c|c|c|c|c|c|c|c|c|}
\hline \multirow{3}{*}{\multicolumn{2}{|c|}{ 年区 分 }} & \multicolumn{2}{|c|}{ 計 } & \multicolumn{2}{|c|}{ 男 } & \multicolumn{2}{|c|}{ 女 } & \multirow{3}{*}{$\begin{array}{l}\text { 性 比 } \\
259.5\end{array}$} \\
\hline & & \multirow{2}{*}{$\frac{\text { 害 数 }}{1,546}$} & \multirow{2}{*}{$\frac{96}{100.0}$} & \multirow{2}{*}{ 奏 数 } & \multirow{2}{*}{$\frac{\mathscr{6}}{72.1}$} & \multirow{2}{*}{$\frac{\text { 実 数 }}{430}$} & \multirow{2}{*}{$\frac{\%}{27.9}$} & \\
\hline & & & & & & & & \\
\hline & 94 & 100.0 & 67 & 71.3 & 27 & 28.7 & 248.1 \\
\hline \multicolumn{2}{|c|}{ 明 $44 \sim$ 大 4} & 68 & 100.0 & 51 & 75.0 & 17 & 25.0 & 300.0 \\
\hline \multicolumn{2}{|c|}{ 大正 5 9 } & 112 & 100.0 & 92 & 82.2 & 20 & 17.9 & 460.0 \\
\hline \multicolumn{2}{|c|}{ 大正 $10 \sim 14$} & 128 & 100.0 & 101 & 78.9 & 27 & 21.1 & 374.1 \\
\hline \multicolumn{2}{|c|}{ 昭和 $1 \sim 5$} & 149 & 100.0 & 115 & 77.2 & 34 & 22.8 & 338.2 \\
\hline \multicolumn{2}{|c|}{ 睛租 $6 \sim 10$} & 222 & 100.0 & 161 & 72,5 & 61 & 27.5 & 263.9 \\
\hline \multicolumn{2}{|c|}{ 昭和 $11 \sim 15$} & 246 & 100.0 & 177 & 72.0 & 69 & 28.1 & 256.5 \\
\hline \multicolumn{2}{|c|}{ 繁和 $16 \sim 20$} & 218 & 100.0 & 154 & 70.6 & 64 & 29.4 & 240.6 \\
\hline \multicolumn{2}{|c|}{ 昭和 $21 \sim 25$} & 142 & 100.0 & 89 & 62.7 & 53 & 37.3 & 167.9 \\
\hline \multicolumn{2}{|c|}{ 炤和 $26 \sim 30$} & 97 & 100.0 & 60 & 61.9 & 37 & 38.1 & 162.2 \\
\hline \multicolumn{2}{|c|}{ 照和 $31 \sim 32$} & 21 & 100.0 & 14 & 66.7 & 7 & 33.3 & 200.0 \\
\hline & 49 & 100.0 & 35 & 71.4 & 14 & 28.6 & 250.0 \\
\hline \multirow{4}{*}{ 瘕 } & $\mathbf{L}$ & 875 & 100.0 & 658 & 75.2 & 217 & 24.8 & 322.6 \\
\hline & $\mathbf{M}$ & 250 & 100.0 & 154 & 61.6 & 96 & 38.4 & 160,4 \\
\hline & $\mathrm{N}$ & 342 & 100.0 & 251 & 73.4 & 91 & 26.6 & 275.8 \\
\hline & 不 辣 & 79 & 100.0 & 53 & 67.1 & 26 & 32.9 & 203.9 \\
\hline \multirow[t]{2}{*}{ 型 } & 訫 & 1.546 & 100.0 & 1,116 & 72.1 & 430 & 27.9 & 259.5 \\
\hline & $\mathrm{M}+\mathrm{N}$ & \multicolumn{2}{|c|}{1.48} & \multicolumn{2}{|c|}{1.62} & \multicolumn{2}{|c|}{1.1} & \\
\hline
\end{tabular}

第 6 図 発痑㭙期别性比

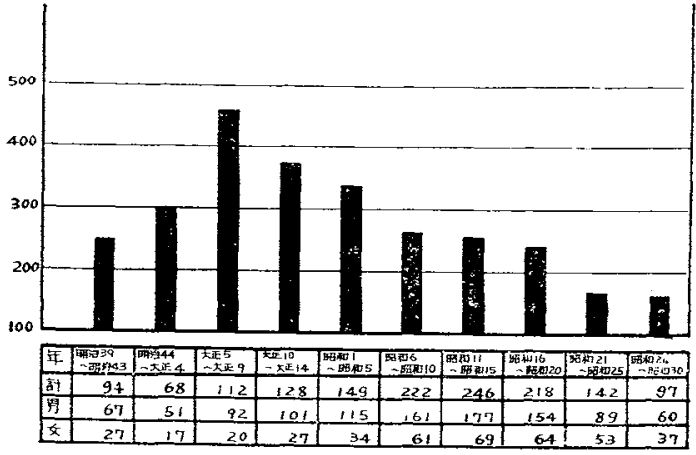

\%男が志め，女は24.8\%のみで，その性比は322.6で ある。M型では，男は61.6\%と全病型中，男の占好る割 合性最も少ない。即台，支の性比は 160.4であるが，こ のことは女子で恬子に比し，L型が少なく，M型の上 める豐合が比較的多いこと意昧している。

病型比它性别にみると男 1.62 に対し，女では1.16と 極めて小さい。

N型では男の73.4\%に対し，女では26.6\%で，その性 比は275.8 と，ほぼL型・M型の中間の犆宗してい る。

\section{c）発病時期別病型別性比（第11表）}

発病時期別に病型別に性此の変遷学みると，L型では 明治末期の228.57より，時代の経過とともに性比は増大
第11表 発病時期別病型別性比

\begin{tabular}{|c|c|c|c|c|}
\hline 年 区 分 & $\mathrm{L}$ & M & $\mathrm{N}$ & 計 \\
\hline 明治 $39 \sim 43$ & 228.6 & 233.3 & 2.800 & 248.1 \\
\hline 明44～天 4 & 483.3 & 133.3 & 360.0 & 300.0 \\
\hline 大正 $5 \sim 9$ & 400.0 & 220.0 & $1,050.0$ & 460.0 \\
\hline 大正10 14 & 557.1 & 57.1 & 283.3 & 374.1 \\
\hline 炤和 $1 \sim 5$ & 339.1 & 240.0 & 287.5 & 338.2 \\
\hline 昭和 $6 \sim 10$ & 280.5 & 200.0 & 311.1 & 263.9 \\
\hline 軋和 $11 \sim 15$ & 284.4 & 235.3 & 229.4 & 256.5 \\
\hline 昭和 $16 \sim 20$ & 268.8 & 150.0 & 223.5 & 240.6 \\
\hline 昭利 $21 \sim 25$ & I 65.4 & 114.3 & 240.0 & 167.9 \\
\hline 昭和 $26 \sim 30$ & 344.4 & 100.0 & 183.3 & 162.2 \\
\hline 昭和 $31 \sim 32$ & 266.7 & 100.0 & - & 200.0 \\
\hline 不 & 366.7 & 400.0 & 200.0 & 250.0 \\
\hline 計 & 322.6 & 160.4 & 275.8 & 259.5 \\
\hline
\end{tabular}

し，大正末期には557.14と最大を示したが，ての㣪は 次第に減少し，戦争ならびに去机に附ずい寸る生活環境 の变化にも著明な影響家みせず減少をみせた。戦後昭和 26〜30年には344.44と急激に性比の増大を希たが，最近 では再び266.66とやや減少の傾向がうかがわれる。

M型では，明治末期233.33より，その後は時代の経過 とともに増隇を多せつつ経過したが，昭和11年頃より漸 次減少し，最近では100.0\%示している。

$\mathrm{N}$ 型の経過は，明治末期280.00より，その後は次第に 增加をみせ，昭和 6〜10年には311.11となつた。更に艺 の後はほぼ230前後にて経過し，昭和26３0年には183.3 と減少它双せている。

即ち，し型では昭和に入つて以来，傾調な性比の淢少

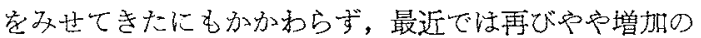
様相定みせているが，M型，N型では減少多著明である。

7) 推定発病季節（第12表）

第12表 推定発病季節男女別病型别

\begin{tabular}{|c|c|c|c|c|c|}
\hline \multirow{2}{*}{ 区 分 } & 春 & 後 & 秋 & 冬 & \multirow{2}{*}{ 計 } \\
\hline & $3 \sim 5$ 月 & $6 \sim 8$ 月 & $9 \sim 11 月$ & 12 2 月 & \\
\hline 計 & $259(35.5)$ & $154(21.2)$ & $130(17.9)$ & $185(25.4)$ & $728(100.0)$ \\
\hline 興 & $196(37.2)$ & $107(20.3)$ & $90(17.1)$ & $134(25.4)$ & $527(100.0)$ \\
\hline 女 & $63(31,3)$ & $47(23.4)$ & $40(19.9)$ & $51(25.4)$ & $201(100.0)$ \\
\hline $\mathrm{L}$ & $156(36.6)$ & $93(21.8)$ & $70(16.4)$ & $107(25.1)$ & $426(100.0)$ \\
\hline M & $53(34.0)$ & $30(19.2)$ & $33(21.2)$ & $40(25.6)$ & $156(100.0)$ \\
\hline $\mathrm{N}$ & $50(34.2)$ & $31(21.2)$ & $27(18.5)$ & $38(26.0)$ & $146(100.0)$ \\
\hline$\frac{\mathrm{L}}{\mathrm{M}+\mathrm{N}}$ & 1.5 & 1.5 & 1.2 & 1.4 & 1.4 \\
\hline
\end{tabular}


発病月の推定される患者 728 名について推定発病季節 をみると，春比発病をみたるのは全体の $35.3 \%$ で最も多

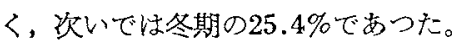

病型别にみると，L型で若千この傾向がみられるが 他の病型で注季節的変化はうかが光ず，病型比をみてる 季節による差巽注殆えどるられない。

\section{8）家族集積性（第13表）}

患者 1,546名について，その世带数は1,351 世带であ るが，世带内患者をてみると総計 1,820 名に及んでい る。即台，469名の患者は本調査にるかかわらず，いえ ペいせられていたもので，掌握患者 1,546 名の30.4\%に あたつていることは，らい予防上重要な意義有する。

第13表 地区別家族集積性

\begin{tabular}{|c|c|c|c|c|c|c|c|c|}
\hline 地 & 区 別 & \multicolumn{2}{|c|}{ 名 古 叚 } & 尾＼cjkstart張 & 西 三 河 & 東 三 河 & 㙖区不詳 & \multirow{2}{*}{$\frac{\text { 計 }}{1,045(77.4)}$} \\
\hline \multirow{8}{*}{ 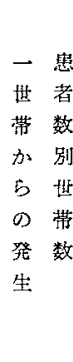 } & 1 名 & & $320(85.6)$ & $422(75.2)$ & $205(73.5)$ & $89(70.6)$ & $9(81.8)$ & \\
\hline & 2 名 & & $35(9.4)$ & $84(15.0)$ & 54 (19.3) & $26(20.6)$ & $1(9.1)$ & $200(14.8)$ \\
\hline & 3 名 & & $11(2.9)$ & $35(6.2)$ & $12(4.3)$ & $6(4.8)$ & - & $64(4.7)$ \\
\hline & 4. 名 & & $5(1.3)$ & $14(2.5)$ & $6(2.1)$ & $4(3.2)$ & $I(9.1)$ & $30(2.2)$ \\
\hline & 5 名 & & $3(0.8)$ & $5(1.0)$ & $2(0.7)$ & - & - & $10(0.7)$ \\
\hline & 6 名 & & - & - & - & $I(0.8)$ & - & $I(0.1)$ \\
\hline & 7 名 & & - & $1(0.2)$ & - & - & - & $1(0.1)$ \\
\hline & 計 & & $374(100.0)$ & $561(100.0)$ & $279(100.0)$ & $126(100.0)$ & $11(100.0)$ & $1,351(100.0)$ \\
\hline 総 患 & 老 数 & & 458 & 783 & 383 & 181 & 15 & 1,820 \\
\hline 家痴集 & 患者数 & & 138 & 361 & 178 & 92 & 6 & 775 \\
\hline 1 世带当 & 愚著数 & & 1.22 & 1.40 & 1.37 & 1.44 & 1.36 & 1.35 \\
\hline 家 笶 & 䅡 率 & & 30.1 & 46.1 & 46.5 & 50.8 & 40.0 & 42.6 \\
\hline
\end{tabular}

第14表 発病から収容までの期間

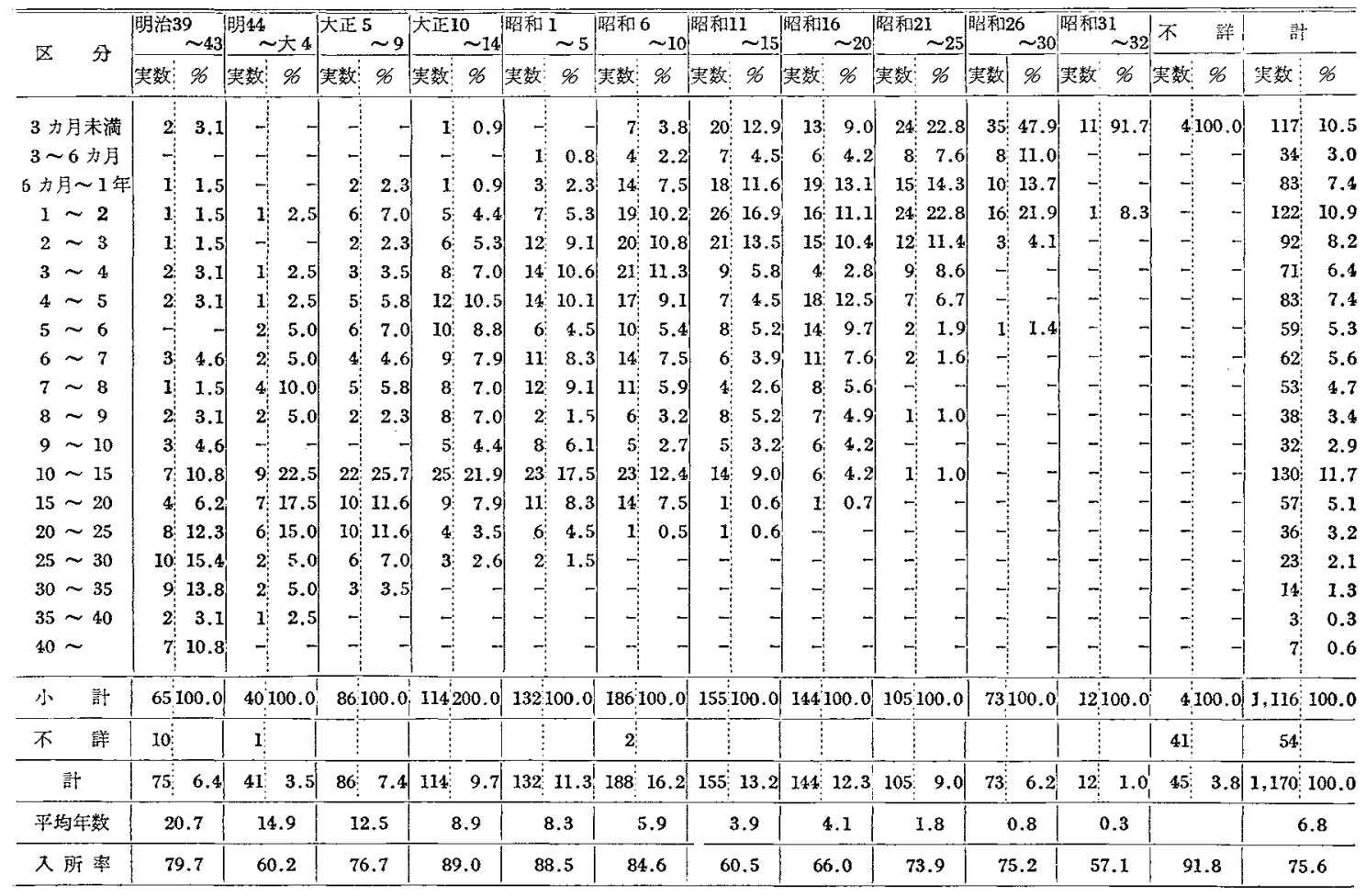


第15表 発病年令別発病から収容字での期間

\begin{tabular}{|c|c|c|c|c|c|c|c|c|c|c|c|c|c|c|c|c|c|c|c|c|}
\hline \multirow{2}{*}{ 年 } & \multicolumn{2}{|c|}{$0 \sim 4$} & \multicolumn{2}{|c|}{$5 \sim 9$} & \multicolumn{2}{|c|}{$10 \sim 14$} & \multicolumn{2}{|c|}{$15 \sim 19$} & \multicolumn{2}{|c|}{$20 \sim 24$} & \multicolumn{2}{|c|}{$25 \sim 29$} & \multicolumn{2}{|c|}{$30 \sim 34$} & \multicolumn{2}{|c|}{$35 \sim 39$} & \multicolumn{2}{|c|}{$40 \sim 45$} & \multicolumn{2}{|c|}{$45 \sim 49$} \\
\hline & 実数 & $\%$ & 実数！ & $\%$ & 実数 & $\%$ & 実数 & 96 & 実数 & $\%$ & 実数 & 96 & 実数 & 96 & 害数 & 96 & 実数 $\vdots$ & 96 & 実数 & 96 \\
\hline 3 力月末强 & - & - & 4 & 6.1 & 14 & 7,7 & $10:$ & 4.2 & 11 & 5.7 & 10 & 7.6 & 16 & 21.2 & 8 & 13.2 & 9 & 24.4 & 6 & 15.7 \\
\hline $3 \sim 6$ 为用 & 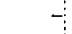 & & 3 & 4.6 & 5 & 2.8 & 6 & 2.5 & 4 & 2.I & 3 & 2.3 & 2 & 2.7 & 1 & 1.6 & 3 & 8.1 & 3 & 7.9 \\
\hline $6 力 月 \sim 1$ 年 & - & & 5 & 7.6 & 9 & 5.0 & 10 & 4.2 & 22 & 11.4 & 14 & 10.5 & 6 & 8.0 & 2 & 3.3 & 3 & 8.1 & 3 & 7.9 \\
\hline $1 \sim 2$ & 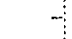 & - & 8 & 12.1 & 14 & 7.7 & 32 & 13.3 & 16 & 8.3 & 18 & 13.6 & 7 & 9.3 & 5 & 8.2 & 3 & 8.1 & 2 & 5.3 \\
\hline $2 \sim 3$ & 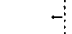 & - & 2 & 3.0 & 20 & 11.0 & 17 & 7.1 & 15 & 7.8 & $6 !$ & 4.6 & 8 & 10.7 & 6 & 9.8 & 1 & 2.7 & 5 & 13.2 \\
\hline $3 \sim 4$ & - & -1 & 3 & 4.5 & 13 & 7.1 & 21 & 8.8 & 17 & 8.8 & 4 & 3.0 & 4 & 5.3 & 5 & 8.2 & - & - & 2 & 5.3 \\
\hline $4 \sim 5$ & - & & 3 & 4.6 & 12 & 6.6 & $2 \mathrm{~T}$ & 8.8 & 17 & 8.8 & 7 & 5.3 & 2 & 2.7 & 7 & 11.5 & 3 & 8.1 & 4 & 10.5 \\
\hline $5 \sim 6$ & $\therefore$ & - & 5 & 7.6 & 10 & 5.5 & 13 & 5.1 & 11 & 5.7 & 6 & 4.6 & 3 & 4.0 & 3 & 4.9 & 3 & 8.1 & 2 & 5.3 \\
\hline $6 \sim 7$ & - & & 6 & 9.1 & 15 & 8.2 & 10 & 4.2 & 12 & $6.2^{\prime}$ & $9:$ & 6.8 & 3 & 4.0 & 3 & 4.9 & 1 & 2.7 & 1 & 2.6 \\
\hline $7 \sim 8$ & - & & - & - & 9 & 5.0 & $19^{\circ}$ & 7.9 & 7 & 36 & 7 & 5.3 & 3 & 4.0 & 2 & 3.3 & - & - & 3 & 7.9 \\
\hline $8 \sim 9$ & - & & 2 & 3.0 & 11 & 6.0 & 9 & 3.8 & 4 & 2.1 & 4 & 3.0 & 4 & 5.3 & 3 & 4.9 & - & -1 & - & - \\
\hline $9 \sim 10$ & - & & 2 & 3.0 & 4 & 2.2 & $10:$ & 4.2 & 6 & 3.1 & 4 & 3.0 & 2 & 2.7 & 2 & 3.3 & 1 & 2.7 & 1 & 2.6 \\
\hline $10 \sim 15$ & - & & 9 & 13.6 & 25 & 13.7 & 29 & 12.1 & 24 & 22.4 & 16 & 12.1 & 5 & 6.7 & $11:$ & 18.1 & 5 & 13.5 & 4 & 10.5 \\
\hline $15 \sim 20$ & - & & 3 & 4.6 & 7 & 3.9 & 14 & 5.8 & 13 & 6.7 & 8 & 6.1 & 5 & 6.7 & 1 & 1.6 & 2 & 5.4 & 2 & 5.3 \\
\hline $20 \sim 25$ & 1 & 100.0 & 5 & 7.6 & 2 & 1.1 & $11 !$ & 4.6 & 5 & 2.6 & 4 & 3.0 & 3 & 4.0 & 1 & 1.6 & 3 & $8 . I^{\prime}$ & - & - \\
\hline $25 \sim 30$ & - & & 4 & 6.1 & 5 & 2.8 & 2 & 0.8 & 3 & 1.6 & 6 & 4.6 & 2 & 2.7 & 1 & 1.6 & 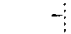 & - & - & - \\
\hline $30 \sim 35$ & - & & $\mathbf{1}$ & 1.5 & 3 & 1.7 & 2 & 0.8 & 4 & $2 . \mathrm{I}$ & 4 & 3.0 & 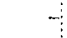 & & - & - & - & - & - & - \\
\hline $35 \sim 40$ & $\stackrel{-}{-\vdots}$ & & $\mathbf{I}$ & 1.5 & - & - & $\mathbf{1}$ & 0.4 & - & - & 1 & 0.8 & 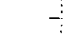 & - & - & - & - & - & - & - \\
\hline $40 \sim$ & - & & - & & 3 & 1.7 & 1 & 0.4 & 2 & 1.0 & 1 & 0.8 & - & -1 & - & - & - & - & - & - \\
\hline 小 計 & 1 & 100.0 & 66 & 100.0 & 181 & 100.0 & 238 & 100.0 & 193 & $100.0^{\prime}$ & $132:$ & $100.0^{\prime}$ & & 100.0 & 61 & 100.0 & 37 & 100.0 & 38 & 100.0 \\
\hline 不詳 & $\vdots$ & & 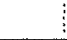 & & 1 & & 2 & & : & & $\mathbf{1}$ & & $1 \vdots$ & & $\vdots$ & & 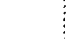 & & 1 & \\
\hline 話 & 1 & & 66 & & 182 & & 240 & & 193 & & 133 & & 76 & & $61 \vdots \vdots$ & & 37 & & 39 & \\
\hline 平均年数 & 22 & & & 0 & & .5 & 7 & .3 & & 3 & 8 & .4 & & .8 & 6 & .0 & 4 & & & 1.6 \\
\hline 大所䊂 & 100 & & 90 & & 93 & & 93 & & 82 & & 74 & & 66 & & 62 & & 56 & & & .7 \\
\hline 年宗嘴测 & $50 \sim$ & & $55 \sim$ & & $60-$ & & $65 \sim$ & & $70-$ & & $75 \sim$ & & $80 \sim$ & & 不 & 詳 & 竐 & & & \\
\hline 期閪 & 完数 & 96 & 実数 & $\%$ & 実数 & 98 & 実数 & 96 & 実数 & $\%$ & 実数 & 96 & 実数 & $\%$ & 夷数 & 96 & 奏数 & $\%$ & & \\
\hline 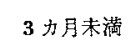 & 8 & 22.9 & 9 & 41.0 & 4 & 23.5 & 4 & 50.0 & 2 & 40.0 & $\mathbf{1}$ & 33.3 & 1 & 100.0 & - & -1 & 117 & 10.5 & & \\
\hline $3 \sim 6$ 方负 & 2 & 5.7 & 1 & 4.5 & 1 & 5.9 & - & & - & - & - & & i⿱ & - & - & - & 34 & 3.0 & & \\
\hline 6 力月～1年 & 3 & 8.6 & 3 & 13.6 & 2 & II.8 & - & & - & - & 1 & 33.3 & 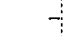 & - & - & - & 83 & 7.4 & & \\
\hline $1 \sim 2$ & 5 & 14.3 & 4 & 18.2 & 3 & 17.7 & 2 & 25.0 & 2 & 40.0 & - & & - & -1 & 1 & 33.3 & 122 & 10.9 & & \\
\hline $2 \sim 3$ & 5 & 14.3 & 3 & 13.5 & 3 & 17.7 & - & & - & - & $-\vdots$ & & - & - & 1 & 33.3 & 92 & 8.2 & & \\
\hline $3 \sim 4$ & 1 & 2.9 & - & & 1 & 5.9 & - & - & - & - & - & & - & - & - & - & 71 & 6.4 & & \\
\hline $4 \sim 5$ & 3 & 8.6 & - & - & 2 & 11.8 & 1 & 12.5 & 1 & 20.0 & - & - & - & - & - & - & 83 & 7.4 & & \\
\hline $5 \sim 6$ & 2 & 5.7 & 1 & 4.6 & - & - & - & & - & - & - & & - & - & - & - & 59 & 5.3 & & \\
\hline $6 \sim 7$ & 13 & 2.9 & - & - & 1 & 5.9 & - & - & - & - & - & - & - & - & - & - & 62 & 5.6 & & \\
\hline $7 \sim 8$ & 1 & 2.9 & - & - & - & - & 1 & 12.5 & - & - & 1 & 33.3 & - & $H$ & -3 & - & 53 & 4.7 & & \\
\hline $8 \sim 9$ & - & - & 1 & 4.6 & - & - & - & - & - & - & - & - & $-i$ & - & - & - & 38 & 3.4 & & \\
\hline $9 \sim 10$ & - & - & - & - & - & - & - & - & - & - & - & - & - & - & - & - & 32 & 2.9 & & \\
\hline $10 \sim 15$ & 1 & 2.9 & - & - & - & $\rightarrow$ & - & - & - & - & - & & 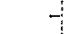 & - & 1 & 33.3 & 130 & 11.7 & & \\
\hline $15 \sim 20$ & 2 & 5.7 & - & - & - & - & - & - & - & - & - & - & - & - & - & - & 57 & 5.1 & & \\
\hline $20 \sim 25$ & $I$ & 2.9 & - & - & - & - & - & 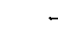 & - & - & - & - & - & -1 & - & - & 36 & 3.2 & & \\
\hline $25 \sim 30$ & - & & - & - & - & - & - & - & - & - & - & - & 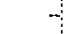 & -1 & 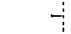 & - & 23 & 2.1 & & \\
\hline $30 \sim 35$ & 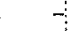 & -1 & - & - & - & - & - & - & - & - & - & - & - & - & - & - & 14 & 1.3 & & \\
\hline $35 \sim 40$ & - & - & - & - & - & - & - & - & - & - & - & - & - & - & - & - & 3 & 0.3 & & \\
\hline $40 \sim$ & - & & - & & - & - & - & - & - & - & - & & 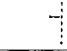 & - & $\begin{array}{r}-\vdots \\
\vdots \\
-\vdots\end{array}$ & & 7 & 0.6 & & \\
\hline 小 柿 & 35 & 100.0 & 22 & 100.0 & 17 & 100.0 & 8 & 100.0 & & 100.0 & 3 & 100.0 & & 100.0 & 3 & 100.0 & 1,116 & 100.0 & & \\
\hline 不詳 & & & & & & & 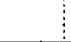 & & 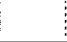 & & 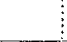 & & $\vdots$ & & 48 & & 54 & & & \\
\hline 竍 & 35 & & 22 & & 17 & & 8 & & 5 & & 3 & & $1 \vdots$ & & $51 !$ & & 1,170 & & & \\
\hline 平均年数 & 3 & .3 & & .4 & & .0 & 2. & .0 & & .7 & & .5 & & .1 & & & 6. & & & \\
\hline 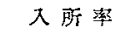 & 61 & & 52 & & 48 & & 53. & & 45 & & 50 & & 25 & & & & 75 . & & & \\
\hline
\end{tabular}


一世带当り患者数は1.35名であるが，一世帶一名の患 者発生世帯が最も多く77.4\%を占めている。

一世带 2 名以上の患者を有するの法 306 世带, 775 名 の患者安保有し，家族集積率は $42.9 \%$ に及てでいる。

家族集䅡性を地域別にみると，東三河地方に最も高く $50.8 \%$ に及び, 名古屋市では $30.1 \%$ と最も低い。

\section{9）療養所への収容状況}

患者総数 1,546 名中，50年間に療養所一収容された患 者は総数 1,170 名で $75.6 \%$ にのぼつている。

a) 発病時期別発病から叹容までの期間（第14表）

収容患者 1,170 名の平均在宅期間は 6.8 年であるが, 発病時期別にみると，占い時代ほど，在它期間も長く， 近年になるほど短かくなつている。即方，明治末期には 平均年数20.7年を要して，全患者の $79.7 \%$ を收容してい るが，発病以来，1力年以内以療養所へ収容された患者 は，わずか $4.6 \%$ の3名のみで，10力年以内の收容者も 僅々 $26.6 \%$ 占めるにすぎず，30年以上の経過者を 27.7 \%にみることは感染源として重大である。

大正時代に入ると，その初期では平均年:数14.9年で収 容率 $60.2 \%$ 己平均年数の短絠に比し，収容率の低下を友 ているが，10年以内の収容者は $32.5 \%$ とやや向上をみせ ている。その後は次第に平均収容年数の短縮, 収容率の 向上，10年以内収容率の向上を示し，昭和時代に注更に この傾向堂強めている。しかし, 昭和11年以降の現象と
して，10年以内収容率は著しい向上を多せているのに反 し全収容率はむしろ低下をみせ $60 \%$ 前後で 経過してい る。このこと注戦争突入による收容かえ奖等行政措置の 低下や国民の意愁の変化によるものであるう。

しかし，戦後注再び全收容率も向上を双正平均年数の 著しい短維とともに1年以内の収容率むほぼ50\%に历え でいる。

\section{b）癷病年令別発病から取容までの期間（第15表）}

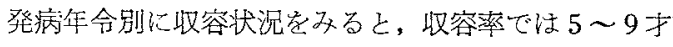

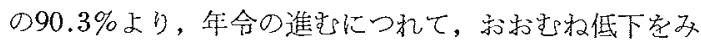
せているが，とくに60才以上の高令層では発病者のほぼ 1/2の収容率を示すにすぎない。

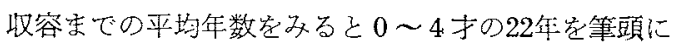

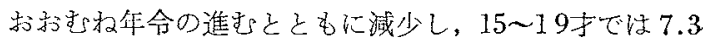
年, 35 39才では 6.0年, 60 才以上では殆んど 2 力年以 内学示している。即ち, 若年の発病者は,いず机艺の 殆えぞが入所するが，入所するまでの在宅期間が長期に わたる傾向を有し，反対に高年令発病者では，入所卞る 意志のあるものは此較的短期間の中に入所老みるが，收 容率梳年層ほど高くはなく、たかだか50\%程度である ことを示している。

\section{c）年次別収容年令（第16表求よび第 7眓）}

療養所へ収容した患者の，発病時期別の收容年命芝乙 ると，明治末期に発病した虫者の平均收容時年令は 40 .

第16表 発病時期別にみた惠者入所時年令

\begin{tabular}{|c|c|c|c|c|c|c|c|c|c|c|c|c|c|c|c|c|c|c|c|c|c|c|c|c|c|}
\hline \multirow{2}{*}{ 区 } & \multirow{2}{*}{ 分 } & \multicolumn{2}{|c|}{ 明治39 43 } & \multicolumn{2}{|c|}{ 明 $44 \sim 大 4$} & \multicolumn{2}{|c|}{ 大正 $5 \sim 9$} & \multicolumn{2}{|c|}{ 大正 $10 \sim 14$} & \multicolumn{2}{|c|}{ 昭和 $1 \sim 5$} & \multicolumn{2}{|c|}{ 昭和 $6 \sim 10$} & \multicolumn{2}{|c|}{ 昭和11 15 } & \multicolumn{2}{|c|}{ 䧄和 $16 \sim 20$} & \multicolumn{2}{|c|}{0 思和 $21 \sim 25$} & \multicolumn{2}{|c|}{ 昭和 $26 \sim 30$} & \multicolumn{2}{|c|}{ 昭和 $31 \sim 32$} & \multicolumn{2}{|r|}{ 計 } \\
\hline & & 实数: & .6 & 実数: & $\%$ & 夷数 & $\%$ & 奖数 & 96 & 奏数: & $\%$ & 実数 & $\%$ & 実数 & $\%$ & 実数: & $\mathscr{6}$ & 奖数 & 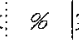 & 実数 & $\%$ & 実数: & 9 & 実数 & $\%$ \\
\hline 0 & $\sim 4$ & - & & - & & 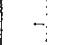 & & - & - & - & - & - & - & - & & $\vdots$ & & - & 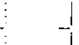 & - & & 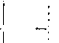 & - & - & \\
\hline 5 & $\sim 9$ & 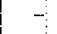 & & - & & - & - & - & - & - & - & 1 & 0.54 & 2 & 1.27 & 2 & 1.44 & 5 & 4.59 & 3 & 4.23 & $-\vdots$ & - & 13 & 1.17 \\
\hline 10 & $\sim 14$ & 1 & 1.41 & $\mathbf{I}$ & 2.50 & 2 & 2.30 & 4 & 3.64 & 5 & 4.03 & 10 & 5.41 & 17 & 10.76 & 10 & 7.19 & 9 & 9.17 & 6 & 8.45 & 2 & 10.53 & 68 & 6.11 \\
\hline 15 & $\sim 19$ & 2 & 2.82 & 1 & 2.50 & 8 & 9.20 & 22 & 20.00 & $16:$ & 12.90 & 27 & 14.59 & 27 & 17.09 & 920 & 14.39 & 9) 16 & 14.68 & 4 & 5.63 & 1 & 5.26 & 144 & 12.94 \\
\hline 20 & $\sim 24$ & 8 & 11.27 & $5:$ & 12.50 & 12 & 13.79 & 21 & 19.09 & 24 & 19.35 & 31 & 16.76 & 27 & 17.09 & 94 & 17.27 & \begin{tabular}{l|l}
75 \\
75
\end{tabular} & 33.76 & 3 & 4.23 & 2 & 10.53 & 172 & 15.45 \\
\hline 25 & $\sim 29$ & 9 & 12.68 & 9 & 22.50 & 16 & 18.39 & 16 & 14.55 & 18 & 14.52 & 57 & 30.81 & 27. & 17.09 & 22 & 15,83 & 15 & $13.76^{1}$ & 7 & 9.86 & 1 & 5.26 & 197 & 17.70 \\
\hline 30 & $\sim 34$ & 8 & 11.27 & 4 & 10.00 & 11 & 12.64 & 14 & 12.73 & 22 & 17.74 & 16 & 8.65 & 19 & 12.02 & 14 & 10.07 & 7) 10 & 9.17 & 10 & 14.08 & - & - & 128 & 11.50 \\
\hline 35 & $\sim 39$ & $11 \vdots$ & 15.49 & 4 & 10.00 & 10 & 11.49 & $11 \vdots$ & 10.00 & 10 & 8.06 & 10 & 5.41 & 12 & 7.59 & 10 & 7.19 & 7 & 6.42 & 7 & 9.86 & 1 & 5.26 & $93 !$ & 8.36 \\
\hline 40 & $\sim 44$ & 6 & 8.45 & 7 & 17.50 & 9 & 10.34 & $11:$ & 10.00 & 11 & 8.87 & 14 & 7.57 & $7^{\vdots}$ & 4.43 & 8 & 5.76 & 2 & 1.83 & 8 & 11.27 & 1 & 5.26 & 84 & 7.55 \\
\hline 45 & $\sim 49$ & 2 & 2.82 & 6 & 15.00 & 5 & 5.75 & 3 & 2.73 & 5 & 4.03 & 6 & 3.24 & 7 & 4.43 & 7 & 5.04 & 7 & 6.42 & $5:$ & 7.04 & 2 & 10.53 & $55^{\vdots}$ & 4.94 \\
\hline 50 & $\sim 54$ & 5 & 7.04 & 2 & 5.00 & 6 & 6.90 & 5 & 4.55 & 6 & 4.84 & 6 & 3.24 & $4:$ & 2.53 & 8 & 5.76 & 6 & 5.50 & 4 & 5.63 & 2 & 10.53 & 34 & 4.85 \\
\hline 55 & $\sim 59$ & 10 & 14.08 & - & & 4 & 4.60 & 2 & 1.82 & 2 & $1.6 \mathrm{I}$ & 4 & 2.16 & 6 & 3.80 & 5 & 3.60 & 6 & 5.50 & 6 & 8.45 & 3 & 15.79 & 48 & 4.31 \\
\hline 60 & $\sim 64$ & 7 & 9.86 & 1 & 2.50 & 2 & 2.30 & - & & 1 & 0.81 & 3 & 1.62 & 2 & 1.27 & 3 & 2.16 & 6 & 5.50 & 2 & 2.82 & 1 & 5.26 & 28 & 2.52 \\
\hline 60 & $\sim 69$ & 2 & 2.82 & $\vdots$ & -1 & 1 & 1.15 & - & & 3 & 2.42 & - & - & $\begin{array}{c}\vdots \\
\vdots \\
\vdots\end{array}$ & & 2 & 1.44 & 2 & 1.83 & 3 & 4.23 & 3 & 15.79 & 16 & 1.44 \\
\hline 70 & $\sim 74$ & - & & - & & $\mathbf{1}$ & 1.15 & 1 & 0.91 & - & & - & - & $-\vdots$ & & 3 & 2.16 & 1 & 0.92 & 1: & 1.41 & $\because$ & - & 7 & 0.63 \\
\hline 75 & $\sim 79$ & - & & 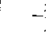 & & - & - & - & & 1 & 0.81 & - & - & $1^{\prime}$ & 0.63 & $-\vdots$ & & 1 & 0.92 & 1 & 1.41 & $-\vdots$ & - & 4 & 0.36 \\
\hline 80 & $\sim$ & - & & - & & $-\vdots$ & - & - & & $\begin{array}{c}\vdots \\
-\vdots \\
\vdots\end{array}$ & & - & - & - & & 1 & 0.72 & - & 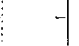 & 1 & 1.41 & $-\vdots$ & - & 2 & 0.18 \\
\hline 小 & 話 & 71 & 100.0 & 40 & 100.0 & 87 & 100.0 & 110 & 100.0 & 124 & $100.0^{\circ}$ & 185 & 100.0 & 158 & 100.0 & 139 & 100.0 & 109 & 100.0 & 71 & 100.0 & $19:$ & $100.0^{\prime}$ & 1113 & 100.0 \\
\hline \multicolumn{2}{|c|}{ 年令不詳 } & & & & & & & & & & & & & & & & & & & & & $\vdots$ & & & \\
\hline & it & 71 & & 40 & & 87 & & 110 & & 124 & & 185 & & 158 & & 139 & & 109 & & 71 & & 19 & & 11.13 & \\
\hline 平均 & 白年令 & & .45 & & 5.00 & & .41 & & 9.27 & & 1.31 & & 8.57 & & 3.01 & & 1.64 & & 1.77 & & 7.63 & & .31 & & 1.84 \\
\hline
\end{tabular}




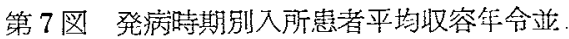
平均在宅期間

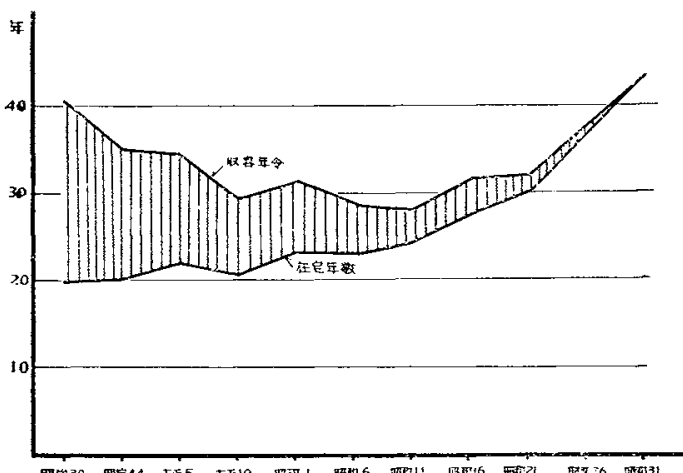

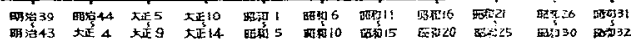

寸で，35〜39才における收容率が最もよく15.5\%となつ ているが，その後，時代の経過と己もに平均収容時年令 注次第に若年化し，同特に29才未啮の収容率の向上をみ ている。大正末期の平均均収容時年合は29.3才，29才末 満の収容状沇は $57.3 \%$ あ゙る。昭和時代に入ると，その 初期で注再び平均収容時年令31.3才とやや老化をみせた

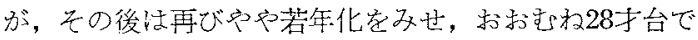
経過与るか，29才米蔳の収容率は，60\%台定示し，向上 娄み婂ている。

仯中の昭和16２0年では平均收容年令は 31.64زとや や增加定双せているが，29才以下の鲁者の取容状沇は $56.1 \%$ 之若干の低下走攵せている。戦後の炤和21２5年 も扮扮む放戦中と同じ傾向であるが，最近の5力年間で

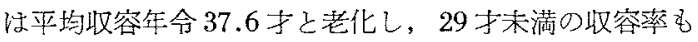
$32.4 \%$ と京り，平均收容年令の老化とともに，収容率の 低下觉みせている。

\section{総括並びに考按}

1) 患者数について

日本のらい患者については，厚生省の行つた数次に放

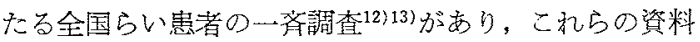
ならびに昭和 8 年に長莤愛生園より出版された日本のら

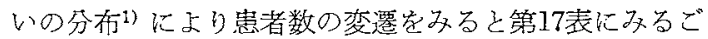
とく，全国では明治30年に19,987人の患者があり，明治 39 年のそ斿 23,815 人，人口 1 万対 5.0 之記載されてい る。その後は全国では濑次減少し，大正 8 年には19,261 名, 万対 2.60 , 大正14年 15,351 人, 万対 2.50 , 昭和 5 年 14,263 , 万対 2.21 , 昭和 8 年 13,241 人となり, その後 も, 人口万対2.1〜2.20経過で昭和30年には約 15,000 , 万対 1.80 と推定されている。

この資料による愛知県の患者数は，明治30年 1,019 人
第17表 全国掌知年次別患者数

\begin{tabular}{|c|c|c|c|c|}
\hline \multirow{3}{*}{ 年 区 分 } & \multicolumn{2}{|c|}{ 厚生省の資料 } & \multicolumn{2}{|c|}{ 譪查 } \\
\hline & 全 & 函 & 受 & 知 \\
\hline & 墨 者 数 & $\begin{array}{l}\text { 令西病堆 } \\
\text { 率 }\end{array}$ & 患 者 数 & $\begin{array}{l}\text { 人日交 } \\
\text { 疗病 }\end{array}$ \\
\hline 明治 $39 \sim 43$ & 23,815 & 5.00 & 94 & 0.53 \\
\hline 明 $44 \sim 大 4$ & - & - & 159 & 0.82 \\
\hline 大正 $5 \sim 9$ & 16,261 & 2.92 & 261 & 1.25 \\
\hline 大正 $10 \sim 14$ & 15.351 & 2.57 & 375 & 1.62 \\
\hline 留科 $1 \sim 5$ & 14,261 & 2.21 & 498 & 1.94 \\
\hline 眧和 $6 \sim 10$ & 15,193 & 2.19 & 656 & 2.29 \\
\hline 蛁和 $11 \sim 15$ & 15,763 & 2.16 & 781 & 2.47 \\
\hline 积和 $16 \sim 20$ & - & - & 771 & 2.47 \\
\hline 昭和 $21 \sim 25$ & 15,000 & 1.80 & 714 & 2.11 \\
\hline 昭和 $26 \sim 30$ & 15,000 & 1.68 & 678 & 1.77 \\
\hline 昭和 $31 \sim 32$ & - & - & 672 & 1.76 \\
\hline
\end{tabular}

より，明治39年 913 人，万対 5.1 より，全国之同様次第 に減少し, 大正 8 年 1,080 人, 万対 5.00 , 大正14年 713 人, 3.00 , 昭和 5 年 590 人, 2.30 , 昭和 8 年 329 人, 1.30 となつている。

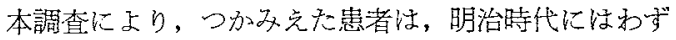
加に94名のみで人口万対 0.5 と著しく低率であつたが，

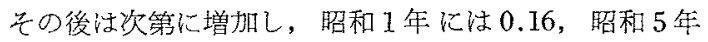
498 人, 1.94, 昭和 10 年 656 人, 万対 2.29 と度り, 昭和 $5 \sim 10$ 年堂境として，それ以前は厚生省の数字の方方本 調查の数字を上廹り，それ以後性本調査の数字の方が， 厚生省数字を上超つている。その後, 本調查では昭租15

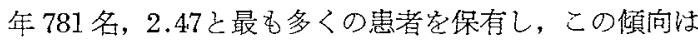
その後も戦中, 践後の10年間にわたつて続いているが, 昭和 30 年末に惊 678 名, 万対1.77实し, 全国の万対坫 とほぼ同様の数字がみられた。

このこ己は，明治・大正特代の患者数は，乙の大部分 が，今日で注資料不㒉のため調查不能となつていること を意味するるので，蟌者そのすのが少なかつたわけでは

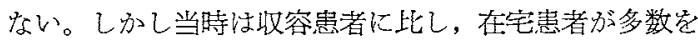

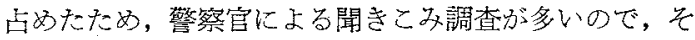
の全部が必らずしもらい疾患であったとも断定しか的る が，いずれにしても，明治時代，大正時代には，本登料 の結果にもか加からず，人口万対 3〜 5 程度の患者が存 在していたことは疑う余地はない。

しかし，らい患者の通性として，㕠名偽名等容易に用 い，同一人で重褑届出登録をみた患者が，本調查全数の 10\%に及几でいるので，過去において警察官等による調

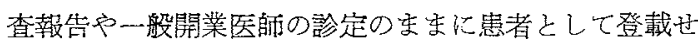
られている厚生省の数字には，当然重複再録等も含をれ 
ていると考光ることは容易である。

ともかくる，らいは，その経過が非常に長期にわたる ため，いつたん収容した患者でも逃走，転園，一時帰省 等の手段により，鄉里へ㷌り，或いは行方不明となつて いるものが $9 \%$ 多きにみら机るため，適確な患教数を 掌握することは非常に困難である。

これらのこと注，療盖所の退所患者，逃走患者，一時 帰省患者等の消急謂査を徹底的儿行うことにより，更に 明確にされるものであるが，このために昭和10年以降の 患者数が本調査では, 唇生省の数字を上廹ることになつ ている。

\section{2）新発生患者比ついて}

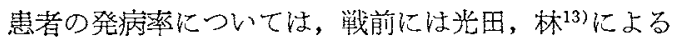
壮丁らいに関する報告坊ある程度であり，こ礼によると 明治時代には壮丁 1,000 に対して1.57〜0.97程度であつ たものが，昭和 10 年には 0.47 となつたと報告されてい

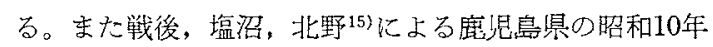
より 22 年に至る間の調查成績では，発生率を人口10万対 4.6 と報告している。

昭和22年 4 月届出伀染病規則の制定以来, 每年の届出 数が衛生年派に記載されるようになつたが、らいという 特殊な疾涔は，医師による誩断決定までに相当の年月を 経過するものとみられ，宮畸 ${ }^{167}$ によらいの進展過程の 研究によつてる明らかな如く，潜伏期，第一次症状期， 移行期, 確改期之経過するむので, 患者の大半は第一次 症状期の後半上り確徽期に至る間に受竦するものと考元 られるので, 当然, 発病の時期と届出の時期の間に㔔な りの期閻が存在することが考六られる。宮崎のいう第一 次症状期の発現時期孛発病時期として考元，本県の新発 生率をみると，戦前，昭和時代に注人口10万対0.9２.3 々前述せる鹿䍐息県のそれに比し，著しく低率であり，

第18表 最近打ける全国愛知届出患者数

\begin{tabular}{|c|c|c|c|c|c|c|c|c|}
\hline & & 区 & 届出 & 擞 ( & 10 万 & 対线） & 本倜查 & (禁知) \\
\hline 笈 & 次 & & 全 & & & & 新患者数 & 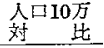 \\
\hline 昭和 & 23 年 & (1948) & 712 & $(0.9)$ & & $(0.4)$ & 33 & 1.0 \\
\hline$"$ & 24 & (1949) & 778 & $(1.0)$ & & $(0.8)$ & 29 & 0.9 \\
\hline$"$ & 25 & (1950) & 604 & $(0.7)$ & & $(0.9)$ & 33 & 0.9 \\
\hline$"$ & 26 & (195I) & 487 & $(0.6)$ & & $(0.5)$ & 20 & 0.6 \\
\hline$\Rightarrow$ & 27 & (1952) & 326 & $(0.4)$ & & $(0.4)$ & 17 & 0.5 \\
\hline$"$ & 28 & (1953) & 315 & $(0.4)$ & & $(0.8)$ & 17 & 0.5 \\
\hline$"$ & 29 & (1954) & 333 & $(0.4)$ & & $(0.8)$ & 18 & 0.5 \\
\hline$"$ & 30 & (1955) & 331 & $(0.4)$ & & $(0.8)$ & 25 & 0.7 \\
\hline$\Rightarrow$ & 31 & (1956) & & - & & - & 13 & 0.3 \\
\hline$n$ & 32 & (1957) & & - & & - & 8 & 0.2 \\
\hline
\end{tabular}

戦後も0.5 1.0となつている。全国のそ礼竞発思者 数よりみると，人口 10 万対，昭和 25 年 1.2 , 炤和 27 年 0.5 , 昭和 30 年 0.5 となつているが，本調查においてる， 昭和 25 年 0.9 , 昭和 27 年 0.5 , 昭和 30 年 0.7 と全国とほぼ 同じ傾向がタられる。

新発生状況㤝，患者数，10万対率之もに，いずれも最 も多くの患者をみた昭和 11〜15 年に至る 5 力年間に比 し, 戦後直ちにすでに $1 / 2$ 強に減少し, 昭和30年末には $1 / 3$ 強となり，更にこ礼が，昭和 32 年には $1 / 12$ 強と著明な 減少をみせている。このことは，大西年の述べる大阪皮 的病砄究所外来患者の統許的観察に上る外来患者の沿和 $11 \sim 13$ 年の数字に比し，戦後は $1 / 2.5$ に減少した事実と同 礿な㑯向をみせ，新患者の減少をみている。

3）在宅患者について（第19表）

第19表 全国・愛知年次別在宅患者数

\begin{tabular}{|c|c|c|c|c|c|c|}
\hline \multirow{3}{*}{ 年 区 分 } & \multicolumn{4}{|c|}{ 厚生省の凟料 } & \multicolumn{2}{|c|}{ 本 謂 查 } \\
\hline & 全 & 国 & 愛 & 知 & 落 & 知 \\
\hline & 在宅䜿者数 & 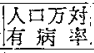 & $\begin{array}{l}\text { 在虫者数 } \\
\end{array}$ & 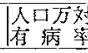 & \begin{tabular}{|l|} 
在密者数 \\
\end{tabular} & 犆口万流率 \\
\hline 明洽 $39 \sim 43$ & 23,605 & 5.00 & 913 & 5.10 & 77 & 0.40 \\
\hline 明 4 更 4 & - & - & - & - & 136 & 0.68 \\
\hline 大正 $5 \sim 9$ & 14,706 & 2.65 & 1,080 & 5.00 & 230 & 1.10 \\
\hline 大正 $10 \sim 14$ & 13,126 & 2.22 & 713 & 3.00 & 321 & 1.38 \\
\hline 昭和 $1 \sim 5$ & 10.991 & 1.72 & 590 & 2.30 & 381 & 1.48 \\
\hline 昭和 $6 \sim 10$ & 8,789 & 1,27 & 329 & 1.30 & 416 & 1.45 \\
\hline 昭和11 15 & 5,817 & 0.81 & 356 & 1.12 & 448 & 1.41 \\
\hline 昭和 $16 \sim 20$ & - & - & - & - & 447 & 1.56 \\
\hline 昭和 $21 \sim 25$ & 2,526 & 0.30 & 250 & 1.08 & 306 & 0.90 \\
\hline 放和 $26 \sim 30$ & 1.113 & 0.12 & 65 & 0.25 & 169 & 0.45 \\
\hline 昭和 $31 \sim 32$ & 1,104 & 0.12 & 44 & 0.15 & 156 & 0.41 \\
\hline
\end{tabular}

在宅患者の帰すうは，感染源として甚だ重要な意味安 もつていること注らうでもないダ，在宅患者の増減 は，や注り新発生患者数に影響するところ大であり，最 も多くの在宅患者学保有したのは，昭和11〜15年の 5 力 年閜で, 448 名を数光, 人口万対 1.41 宗している。在 宅虫者数梳，その後注年経過とともに減少し，昭和21～ 25年の戦争直後では 306 名, 万対 0.90 より, 炤和 $31 \sim 32$ 年汇は 156 名，0.41を示している。これらの数字定全国 ならびに厚生省にて発表されている本県の在宅患者状況 と比べてみると，いずれる相当大巾に本調查成䋶で浪高 い在宅率となつている。とのことは, 前述せる一時㴆省 のまま帰園しない患者や，选走脱走等の患者で消息の判 明したものの中, 在宅しているるの在宅患者数に加え たためであるが，いずれにしても，行政庁にて把握され 
ている在宅登録患者のほぼ 2 倍の患者が存在しているこ とを意味してお和，らい予防上重大な間題と考え的机， 患者管理，とくに败容患者の措置の適正㴗望也ら饥 b。

4) 所謂戦争らいについて

宮崎 ${ }^{18)}$, 高易 ${ }^{19)}$ 性, 今次の太平洋戦争とらい発生上の 留係を論じ，殊に宫㱦は，潜伏をたはそのままの状態で は，発病にまでに至らなかつたかも知れない状態の人が 戦争己いら因難な状況下に遂に発病に至つたと断じ，誘 因として過労, 寒冷, 暑㙓, アメ一心赫㢉, 結核, マラ リヤ，戦稘等をあげており，また Hasseltime ${ }^{201}$ は米西戦 争新よび第一次大戦，Aycock ${ }^{21}$ 注第二次大戦の米国出 征兵士の覴病者について調查した結果是，米西戦争の発 病者は，お括祖米国外での感染で，第一，第二次大戦 のそれは多くその源安米国内の感染に発し，戦争の悪条 件下に発病したものと推定している。

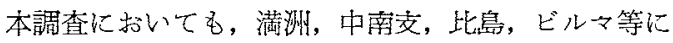
おいて転戦中に発病，或は内地において軍柔に服してい る中に発病せるもの等35例を穵ているが，この35例中， 冢系にらい患者を有するもの8例方り，乙礼らは宮崎の 論ずる如く, 戦争，電隊といら悪条件下に送に発病に至 つたものと推定され，他は外地における新感染発病と考 えられるが，発病時期別の患者数からみてす明らかな姐 く，戦中，戦後の覀条件下にもかかわらず，発病率は既 に昭和 6 - 10年に至る 5 力年間に最大䍜患率学示してお り，昭和20年を中心とした10力年間では，むしろ前半の 5 力年間では若于の, 後半の 5 力年閪ではかなりの新発 病率の低下を多ていることは，前速の例にもか力わら ず，本県患者の発痖状沇には，戦争による影響は殆えど みられなかつたといい得よう。

5) 病型について

病型别には，L型が 864名で59.3\%占めている。病 型比で注全数 1.47 で, 全国潦養开入所㶳者の1.70, 北

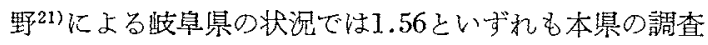
より高くなつている。

病型別の危險度は $\mathrm{L}$ 型で最も宮く、M型は旺盛期なた

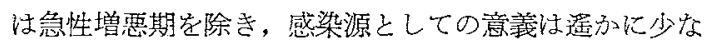
く， $\mathrm{N}$ 型では実際上，殆えど质険はないといわれてお

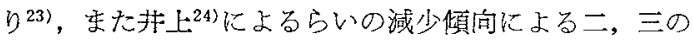
研究によれば, 病型の移動現象, つ交り病型比の淢少は らいの減少過程定意味すると諭じているが，本県におけ る病型比の経過過程は，大正末期上り炤和10年に至る約 15年間淀型比も2.1 2.7家し，L型性盛期ともいう ベき状沿でかつたが，その後は次第に減少し，昭和30年

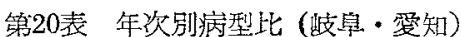

\begin{tabular}{|c|c|c|c|c|c|c|}
\hline \multirow{2}{*}{ 年次别 } & 岐 & \multicolumn{2}{|r|}{ 臬 } & \multicolumn{2}{|c|}{ 骨 } & 知 \\
\hline & $\mathrm{L}$ & $\%$ & $\mathbf{L} / \mathbf{M}+\mathbf{N}$ & $\mathbf{L}$ & $\%$ & $L / M+N$ \\
\hline 明治39 43 & - & - & - & 46 & 5.34 & 0.96 \\
\hline 明 $44 \sim 大 4$ & - & - & - & 35 & 4.06 & 1.12 \\
\hline 大正 $5 \sim 9$ & - & - & - & 70 & 8.13 & 1.79 \\
\hline 大正10 14 & 11 & 6.19 & 0.73 & 92 & 10.69 & 2.70 \\
\hline 昭和 $1 \sim 5$ & 16 & 8.99 & 1.60 & 101 & 11.74 & 2.10 \\
\hline 昭和 $6 \sim 10$ & 30 & 16.85 & 1.67 & 156 & 18.12 & 2.56 \\
\hline 昭和 $11 \sim 15$ & 46 & 25.84 & 2.09 & 123 & 14.29 & 1.09 \\
\hline 昭和 $16 \sim 20$ & 38 & 21.34 & 1.81 & 118 & 13.71 & 1.09 \\
\hline 炤和 $21 \sim 25$ & 26 & 14.60 & 1.73 & 69 & 8.01 & 1.08 \\
\hline 昭和 $26 \sim 30$ & II & 6.19 & 0.85 & 40 & 4.64 & 0.85 \\
\hline 昭和 $31 \sim 32$ & - & - & - & 11 & 1.27 & 1.00 \\
\hline 小 & 178 & 100.00 & 1.56 & 861 & 100.00 & 1.47 \\
\hline 不 詳 & & & & 14 & & 1.75 \\
\hline 計 & 178 & 100.00 & 1.56 & 875 & & 1.47 \\
\hline
\end{tabular}

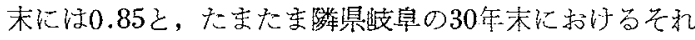
と同じ数字を示している。しかし，滝引125りにり昭和 28 〜29〜30各年の全国届出患者の調査では病型比は0.80と 報告されているとこるからみると，本県の昭和32年の

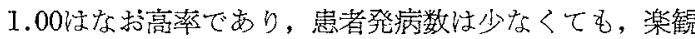
注許されない。

昭和 21 年以降に括ける病型比の淢少法特に著明なM型 の增加， L型の減少によるものである。

更に病型別に収容状況をみる，収容患者では発病後 10年以内に収容されたものはL型69.9\%，M型76.9\%， N型52.8\%で，L型およびM型に多く双られるのは感染 源として喜ばしいが，一方，在宅患者で10年以内のもの はL型37.9\%，M型16.2\%，N型27.5\%で，他注いずれ む10年以上の経過者であることから只ると，な子相当の L型M型患者が長期にわたり在宅していること意味し ており，これらの傾向は，ほぼ北野による跂卓暴のすう 勢と同様である。

6) 発病年令について

従来より，ら以患者の発病年令は 5 于以上の子供と 20 才前後に多く, 30 子以後の発病は比較的少なく, 稀に高

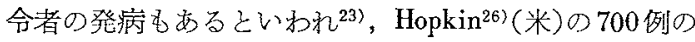
調查でも，その大部分は $9 \sim 30$ 子で発病し，思春期に頂 点に達し，橋本および小松27の7,976人についての調查 でも15年以下の発病者は 1,689人で約21\%占的，11〜 30才でのそれは 5,577 人で約70\%に達していると報告し ている。本暑における発病年命分布も注ほ同様な㑯向を 多せ，15１9才に最高く19.7\%を示し，10２9才に沶 
ける発病は全体の63.1\%を示している。

ただ特異なのは，療養所人入所した患者と在宅患者の 発病年令分布の相違であつて，前者では10〜29才におけ 万発病注67.4\% と Hopkin の調查例とほぼ同じ率を示す のに対し，後者で注わずか36.0\%にすぎず，前者と後者 の間に平均10年の差をみるのは，<19/60<前者 15.1 後者 1.4 と著しい相異を示すこと等加らも在宅鲁者惊 令の発病者の多いことを意味しており，つまり高命発病 者社在宅患者になり易いことがうがわれる。

茾上 ${ }^{24)}$ によるらいの減少僋向ならびに野辺地28》による

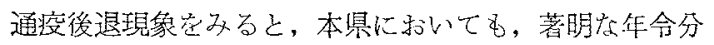
布曲線の不旋小よび舟均年令の上昇， $<39 / 40<$ の減少

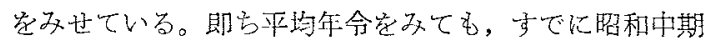

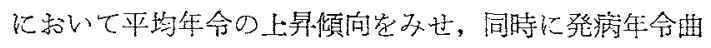

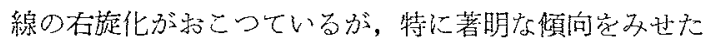

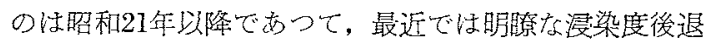
現象を攵せている。

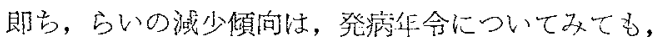

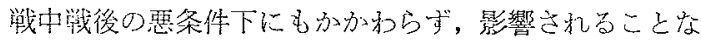
しに続いたものであり，この傾向法北野による枓皋県の すう㢣上全く同様であつた。

また病型別に<39/40<，ならびに<19/60く々をみる と, 特に後者ではL型の 20.3 に対し， N 型9.5，M型2.8 と特にM型に高令者発病が著明であるよらにみらけられ るが，<39/40<ではL型7.1，N型3.1，M型3.3と特に M型にの攵著明ではない。このことからしてM型は他型 に比し，此䡆的各年令㜿に平等に発病者安みているこ之 がうかがわれ，これに対し，L型では若年層に龃る多い ことが多うけら叔る。

7) 性比次いて

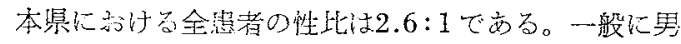

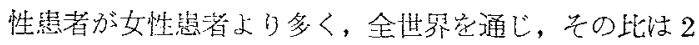

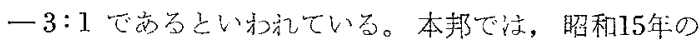
調盗では, 2.2:1, 昭和30年には $1.8: 1$ 苂している。

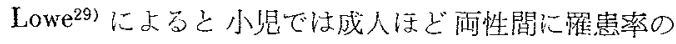
差がなく，15才以上の所語，思春期には女性の羅患率が 高いといつているが，本調查では乞うした傾向はみら和 ず，各発病時期炎通じ，昭和21２5年の15１9才に打い

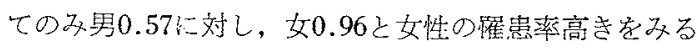
のみであつて，その他の年はいずれも男性の15〜19才玄 たは20〜25才に沶いて，最も高い罹患率をみるのは，或 いは地域性の問題であるう㣻。

また Brockington ${ }^{30}$ は，その著World Health におい て、未開時代ほど性比は大きく，文明の進めば進むほど
性比が減少することを述べているが，本調査の発病時期 別の性比の変遥安办ても, 大正 $5 \sim 9$ 年の間に 4.8 之著 しく高く，その後哖々減少し，昭和 20 年には 1.8 之な つている。このことはまた，非上のいう減少過程を示す I指標でもあつて, 発病年令, 病型比ととも減少傾向 を明白に示しているものといえよう。

\section{8）家族集積性について}

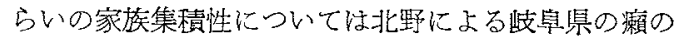
考祭 31 による $23.3 \%$ 述べているが本县に打いては家族集積率 $42.6 \%$ であつた。患が疾惡だけにらいの悲慘さは日にあま るものがあるといえよう。乙かも，地域的にみても，人 口稀藻な山地地方ではとの家族集䅡率も50.8\%に及んで いるが，人口稠密な名古㙠市においてすら $30.1 \%$ にのぼ つていることは、患者家族の発病管理が，いかに重要な ものか如実に物語つている。

9）転㴆について

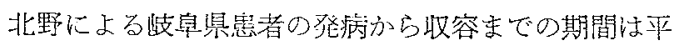
均 7.1 年で，船鼻県では昭和 21 年より25年に至る間が最 む長く, 平均 8.6 年索数光, 最近では 3.1 年上短縮され

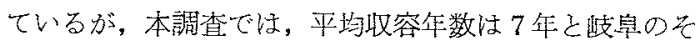
れと全く同じであるが，岐悬県にみる如く，戦後に最も 長い期間它有せず，明治末期の平均 20 年より，時代経過 とともに徐々に縮少し, 戦中, 戦後の影響定うけること なく，最近ではるず数力在示しているにすぎない。

第21表 発病時期別平均收容年平均令在宅期間

\begin{tabular}{|c|c|c|c|c|}
\hline 年 区 分 & 和均收容年-令 & 的在宅獭周 & 入所 率 & 平均登病年命 \\
\hline 明治 $39 \sim 43$ & 40.45 & 20.73 & 79.7 & 22.06 \\
\hline 明 $44 \sim$ 大 4 & 35.00 & I4. 86 & 60.2 & 24.61 \\
\hline 大正 $5 \sim 9$ & 34.41 & 12.49 & 76.7 & 23.43 \\
\hline 大正 $10 \sim 14$ & 29.27 & 8.93 & 89.0 & 21.21 \\
\hline 孡科 $1 \sim 5$ & $31 \cdot 31$ & 8.25 & 88.5 & 23.45 \\
\hline 稳和 $6 \sim 10$ & 28.57 & 5.88 & 84.6 & 24.84 \\
\hline 昭和 $11 \sim 15$ & 28.01 & 3.93 & 60.5 & 28.33 \\
\hline 昭和 $16 \sim 20$ & 31.64 & 4.09 & 66.0 & 32.65 \\
\hline 䏦和 $21 \sim 25$ & 31.77 & 1.83 & 73.9 & 33.17 \\
\hline 昭和 $26 \sim 30$ & 37.63 & 0.76 & 95.2 & 39.60 \\
\hline 昭和 $31 \sim 32$ & 43.31 & 0.28 & 57.1 & 48.90 \\
\hline
\end{tabular}

一方, 收容率についてみると, 明治末期の79.7\%より, 大正時代, 昭和初期にかけては $80 \%$ 以の入所状沉を示 していたが，昭和11年以降壮60\%台に低下し，戦後に至 り, 再び70\%代定示しているが, このこと注戦後, 入所 かえ突等の行政措置が強力に行われたためと考兄られ 
る。しかし平均発满年令の老化ととるに, 叹容率の低下 も予想さ记名が，この僋向はすでに眧租31〜32年におい て57.1\% と低下を东せており, 感染源封策として, 在宅 期閔の短縮のみでなく，収容率の向上が望变れる。

\section{結論}

明治39年上り昭和32年に至るほぼ50年間の愛知県の新

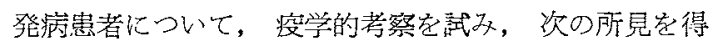
皮。

1）明治39年より㹦和32年に至るほぼ50年間の新発病 患者は 1,546 名で，この新患者発病率は人口 10 万対 0.1 〜1.6で 1 年平玸患者数は 26.7 人であつた。

最も多くの患者発病安双たのは昭和11１5年に至る5 力年間で， 1 年平均患者登病数は50名定示した。その後

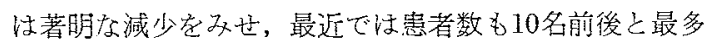
期の $1 / 5$ 程度と減少家みせている。

人口10万対䍜患率についてみて子同様で，昭和 $26 \sim 30$ 年にいたる 5 力年平均㕍患率任 0.5 , 昭和 $31 \sim 32$ 年の 2 力年間では 0.2 乙戦前の $1 / 8$ の減少を子た。

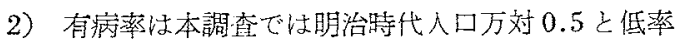
であるが，昭和10年以降泣ほぼ全国平狱の万対有痛率を 示し, 昭和 32 年末には 1.8 となつている。従つて本県に

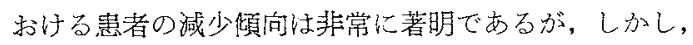
本県には，炤和32年末の登録在宅㶳者50名の他に約 100 名の未登錄患者の存在すること名朋磪となり，このこと はほぼ登録患者の2倍にあたる所謂いえペいらい虫者の あること意味している。

3）発病年合は15〜19才に最も著明で16.7\%宗し, 10〜29才に打方登病は全体の63.1\%を示しているが， 時代により，罢境により若干の相異がタられる。特に収 容患者之在宅患者の発病年令には約10力年のズレが認め ら秃，在宅患者では10〜29于に打ける発病率は36.0\%に みられるのみで女る。即ち収容虫者は若年発病に多く, 在宅患者は高年発痔が多い。

発病年令の年次变化をみると発病年命の後退化が著明 であり，この傾问は既に昭和中期よりみうけられたが， 最近の分布曲線では，青少年峰が消失する傾向にある。

4) 病型, 病型別では L 型59.6\%, M型17.0\%, $\mathrm{N}$ 型 $23.4 \%$ ある。

病型比 $(\mathrm{L} / \mathrm{M}+\mathrm{N})$ は平均 1.47 である肪，年次別の 病型比の变遷で注大正末期2.71に比し，昭和26〜30年に は0.85と病型比の改善が著しい。

病型別に登病年:令をみると，M型では $<19 / 60<$ は 2.0 と L 型07.8，N型4.6亿比し最も小さくまたく
でもM型に2.2 学示している。このことは他型に比し， M型発病恪年含層にわたつているこ乞意味し，とく

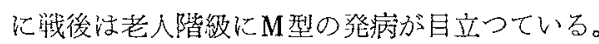

5）性比については，全患者の性比将259.5でかるが， 時期によつて異交り, 大正 5〜9年には 460.0总示した

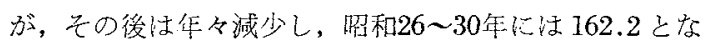
つている。

病型别に注L型の 322.6 に対し，M型 160.4 と最も性 比はさく，N型は 275.8 と衣つている。

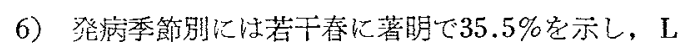
型にこの傾向がうかがわれる他は特に発病と季節の消長 に法特暴性が沈い。

7）家族集積性についてタると，家族集積率42.6\%七 ある。

とくに人口稀薄な山地地方に惟積率著明て50.8\% に 及び，名占屋市に乱ても，家族集積率 $30.1 \%$ を示して いる。

8）療美所への収容状況老みるに総㶳者 1,546名の中 汪ぼ50 年間に収容された患者は1,170名 $75.6 \%$ で女つ た。

1,170 名の収容患者の収容まての期間は， 5 年以内602 名，53.8\%であ。収容状況は時代によつて大いに異つ ており，明治時代には平均20.7年安示したが，その後住 時代の経過と已もに次第に短縮し，昭和 26〜30 年には 0.7 年老示すに至り，年経過と已もに発病期入前の様相 呈している。

発病占り収容までの年数梳平均 6.8 年, 収容までに10 年以上在宅している患都は $24.3 \%$ K及てでいる。

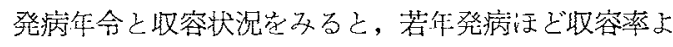
く，高年層ほぞ悪くなつているが，收容をでの期間は若 年層ほど長く，高年層ほど短い。このこと情年層では 長期の在宅を双てむいずれは入所するが，高年層で汪入 所するものほ比䡆的短時口に入所引ること意味してい る。

9）忠者の転㾛以ついては，50年間学通し，略治等の 理由により取消し（忠者台帳より）它うけたものは109 名, $7.05 \%$, 死亡者注 699 名, $45.7 \%$ である。他晨へ転 出したものは僅か 9 名にすぎない。

叹容された患者の中，退所したむのは 138 名て $8.92 \%$ である。退所後再び在宅したものは121名, 残りの17名 は所在不明者である。

10）在肎患者総数は 376 名で全患者の $24.32 \%$ 占め ている。在宅率の高いのは昭和11〜15年の 5 力年間で， 人口万対1.41を示したが，最近では万対0.41となつてい 
る。

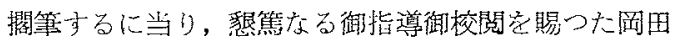
教授に感謝觉献げ，終始御鞭羘御指導賜つた野辺地教 授, 古武教授に深謝致しますと共に, 多大の御援助, 御

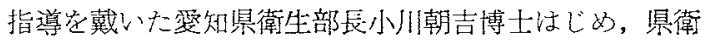
生部諸氏並びに名古屋大学公等衛生学教室, 予防医学教 室員の方々に愿く感謝し安守。

\section{文献}

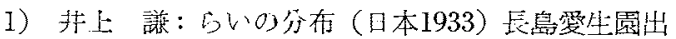
股 (昭 9)

2）厚生省大臣官宥統計調查部：昭和29作衛生华報 厚生省大臣官房統計調查部（昭31）

3）浅野武一：皮黹泌层器利雑誌，20，789（大 9)

4) 田中詀吉：愛知医学会雑誌，41（10）1637(昭 9)

5）清水圭三：名古屋医学会赫誌，49（1）115（昭14）

6）光田健朝：公衆衛生雑誌，57（5）318（昭14）

7）らいの病型シンポジアム:レプラ, 24, 225(炤30)

8）高島重孝：レプラ，24，41（昭30）

9）愛知県統計深：要知県統計言，要知県（明39～眧 32)

10）林 文雄：日本公䍃保健郬会雑誌，14（4） (昭13)

11）林 交雄他：レプラ，10，259（昭14）

12）厚生省予防局：濑患者に関与方統計，厚生省予防 局 (炤17)

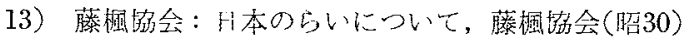

14）光田健輔 - 林 文雄：東京医事新誌 No. 3151： 24. (昭14)

15）塩沼英之助：レプラ，12，33（昭23）

16）宮崎松記：レプラ，11，124（昭15）

17）大无基四头：レプラ，19，27（昭25）

18）宮崎松記：レプラ，17，1（䎏23）

19）高島重孝：レプラ, 17，8（炤23）

20) Hasseltime. H. E. : Internat. J. Lep. 8 501(1940)

21) Aycock W. L. Gorden J. E. : Amer. J. med. Assoc. Sci. $214: 329$ (1947)

22）北野博一: レプラ，26，325（昭32）

23）佐藤三郎他：日本皮唐科全書 IX瀨；金原浊版株 式会社（昭29）

24）井上 諮：濑の減少傾向に関少る二，三の斫究 辱岛愛生总出版（昭24）

25）澺川勝人：レプラ， 26,92（昭 $32 ）$

26) Ralph Hopkins, Oswald E. Denney : Leprosy in the United States, J. Am. Med. Assoc. 92 (3) (1929)

27）槣本・小松：レプラ，6，649（昭10）

28）野辺地慶三：公衆衛生学第 4 輯疫学総論, 日本臨 底社（昭26）

29) Lowe. J. : Internat. J. Lep., 2, 57 (1934)

30) Brockington F.: World Health the Whitefriaris. Press Ltd, London (1958)

31）北野博-：レプラ 27（1）62-72（昭33） 